Rhode Island College

Digital Commons @ RIC

8-16-2020

\title{
Gamification: An Innovative Way to Enhance Health Behaviors for people Living with HIV/AIDs Via Mobile Health Appliacations
}

Chan Sreypouv

Follow this and additional works at: https://digitalcommons.ric.edu/etd

Part of the Medical Sciences Commons

\section{Recommended Citation}

Sreypouv, Chan, "Gamification: An Innovative Way to Enhance Health Behaviors for people Living with HIV/AIDs Via Mobile Health Appliacations" (2020). Master's Theses, Dissertations, Graduate Research and Major Papers Overview. 327.

https://digitalcommons.ric.edu/etd/327

This Thesis is brought to you for free and open access by the Master's Theses, Dissertations, Graduate Research and Major Papers at Digital Commons @ RIC. It has been accepted for inclusion in Master's Theses, Dissertations, Graduate Research and Major Papers Overview by an authorized administrator of Digital Commons @ RIC. For more information, please contact digitalcommons@ric.edu. 
Gamification: An Innovative Way to Enhance Health Behaviors for People Living with HIV/AIDs Via Mobile Health Applications

Sreypouv Chan

Rhode Island College

Master Thesis: Submitted in fulfillment of the requirements for the degree of Master of Science in Health Care Administration in the Graduate program of Rhode Island College, 2020

Committee members:

Associate Professor Marianne Raimondo

Associate Professor Christine Connolly

Assistant Professor Sankeerth Rampa

Paul Loberti, MPH 
TABLE OF CONTENTS

Abstract............................................................ 3

Acknowledgement................................................... 5

Background and Rationale............................................ 6

Literature Review.................................................... 10

Specific Aims........................................................ 15

Methodology ........................................................ 15

TAVIE-HIV Platform............................................... 17

TAVIE-RED Platform............................................. 18

Leaderboard................................................ 20

Challenges/Quests......................................... 20

Setting, Case Selection and Sample.............................. 21

Measured Variable and Survey Instrument........................ 22

Statistical Approach............................................. 23

Result................................................................... 26

TAVIE-HIV Demographics....................................... 27

TAVIE-RED Demographics ...................................... 28

TAVIE-HIV: Depression Severity.............................. 30

TAVIE-RED: Depression Severity................................ 32

Initial Cohort.................................................... 33

Discussion........................................................ 35

Limitation..................................................... 37

Conclusion........................................................... 39

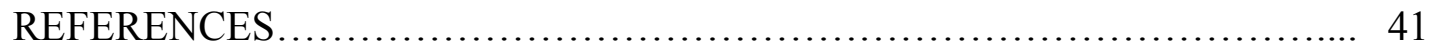

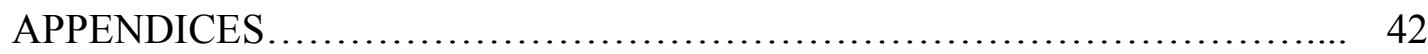




\begin{abstract}
Mobile health applications are known as any wireless technology in medical care and have been considered as one of innovative ways to assist and engage patients in care. This project focused on mobile health applications that were designed specifically for HIV medication adherence and to serve People Living with HIV/AIDs (PLWHA) with their HIV care in Rhode Island (RI) Ryan White Part B program, a federal program that provide HIV care to PLWHA (HRSA,2019). RI-Ryan White program partnered with 360 Medlink, Inc. (a software development company) developed and delivered two advanced digital platforms called TAVIEHIV (an application with no gamification) and TAVIE-RED (an application with gamification) to Ryan White's clients in RI.
\end{abstract}

TAVIE-HIV is a digital platform that is clinically validated and designed to help individuals with HIV to learn the skills required to manage their health conditions, such as managing the medications, medical appointments, learning how to self-monitoring and screening their own anxiety and stress on regular basis (360 Medlink Inc., 2019). TAVIE-RED is the newest version of TAVIE platform is not only clinically validated but could be used to assist users in many different aspects of care/daily activities. For instance, having access to social services such as location for food banks and clinics that specifically provide for PLWH in RI. The main different that TAVIE-RED has is gamification and TAVIE-HIV does not. The program's population is considered as one of the most vulnerable groups of people, $21 \%$ of patients reported homeless and unstable housing, thirty-three percent reported clinical levels of depression, fifty percent reported in need for HIV symptoms management, $20 \%$ reported that they did not have their own cell phone and up to $90 \%$ of the population reported that they did not have smartphone prior to the TAVIE platforms were released (360 Medlink, 2020). 
This study focused on two advanced digital platforms: TAVIE-HIV and TAVIE-RED. The main components of both digital platforms focused on HIV medication adherence for people living with HIV (PLWHA) to achieve their viral load suppression. The aims for this project are (1) to describe how people living with HIV use the two platforms, called TAVIE-HIV and TAVIE-RED, (2) to compare and contrast the use of the two platforms, and (3) to measure client satisfaction with the TAVIE-RED application.

A descriptive study was used in this project to describe how PLWHA used the platforms TAVIE-HIV and TAVIE-RED and how it could be used to support users with HIV medication management as well as symptoms management. Another purpose was to compare the TAVIEHIV and TAVIE-RED platforms to see if there were differences in users' engagement with both applications.

The result of this project showed that gamification in TAVIE-RED earned more interest and engagement from the users compared to TAVIE-HIV. The initial cohort's viral load suppression (initial cohort= participants who got exposed to both platforms with a total of 47) increased from $36.17 \%$ to $74.46 \%$ (September 2018-September 2019). It was found that $95 \%$ of the participants in TAVIE-RED were clinically depressed (mild-severe depressed) based on the PHQ9 scale. This showed how emotional well-being could majorly affect users' daily activities and HIV care. This concluded that gamification was the driving force for the users' engagement for TAVIE-RED and produced more effective results comparing to a non-gamification platform (TAVIE-HIV).

Keywords: gamification, HIV, mobile App healthcare, technology 


\section{Acknowledgements}

This project would not have been possible without the support of many who have been there since the beginning. I would like to express my deepest appreciation to everyone who has supported me from the beginning. Many thanks to Dr. Marianne Raimondo and my committee members Paul Loberti, Dr. Christine Connolly, and Dr. Sankeerth Rampa for offering guidance and tremendous support throughout the process. Without their guidance and persistent help, this project would not have been possible.

In addition, a big thank you to the Program Manager- Data Scientist Andre Parker, and Program Management Methods Analyst Ryan White Provision of Care and Special Population of RI EOHHS who continually conveyed a spirit of adventure in regard to this project. He inspires me to get out of my comfort zone and to use my greatest potential for this project. Mr. Parker is the lead for TAVIE-RED at EOHHS, and the one who brought gamification to TAVIE-RED mobile health platforms for the program. Without his guidance, this project would not be possible either.

Throughout this project, I have learned so many new inspiring things about technology and what it can do to advance our healthcare system. I am beyond grateful for having the opportunity to do my thesis on TAVIE platforms. The EOHHS team truly has inspired me to look at this project with a different pair of eyes. Instead of looking at it as a school project, I took it as an opportunity to learn and discover a completely new different world that I never knew about: gamification and how it was compromised in mobile applications to get people engaged with healthcare. 
Gamification: An Innovative Way to Enhance Health Behaviors for People Living with HIV/AIDs Via Mobile Health Applications

Background and Rationale

Human Immunodeficiency Virus (HIV) has been one of the most concerning health issues in the United States, with approximately 1.1 million Americans living with HIV today. One in seven are unaware of their infection (AIDS.gov, 2019). According to a study conducted in 2016 on 39,782 young males aged between 13-18 years old, young men who have sex with men (YMSM) are at greater risk of getting HIV infections. The findings of the study showed that this population was $21 \%$ newly infected in the United States, and $81 \%$ of these cases are found to be African American and Hispanic young men who have sex with men (Cho et al., 2018).

The occurrence of HIV in the United States is higher in lower socioeconomic groups that lack health services. It is true that everyone is at risk for contracting HIV; however, those at high risk include gay and bisexual men and transgender people (AIDs.gov, 2014). One particular study shows that most of the states with the highest percentage of HIV infections in the U.S. are located in the deep southern states (Breskin et al., 2017). According to the Department of Epidemiology in North Carolina (2016), the majority of those people who get infected are from low-income families. In 2013, Mississippi's prevalence rate ratio of HIV showed that black males are diagnosed with HIV 5.3 times more often compared to white males. Moreover, black females have an HIV diagnosis 9.7 times more often compared to white females (AIDs.gov, 2017).

In the state of RI, it is estimated that about 2,600 of Rhode Islanders were diagnosed and living with HIV through the end of 2015 and about 11 percent of these individuals who are infected with HIV do not know their status (Rhode Island Department of Health [RIDOH], 
2019). From 2008-2016 data, DOH (2019) revealed that the overall newly diagnosed HIV infections decreased. However, the year of 2014, the number of people diagnosed with HIV increased. The reason why was not clearly known (Figure 1).

There are organizations in Rhode Island that provide HIV care to those individuals who are infected. Those organizations include Miriam hospital, AIDS Project Rhode Island, AIDS Care Ocean State, and Community Care Alliance. Many of these agencies are funded by the RI Ryan White Program. The Ryan White HIV/AIDS Program is a federal program that provides HIV-related health services that are funded by The Health Resources and Services Administration (HRSA). This grant program provides different services to HIV positive individuals such as primary medical care, essential support services and medication for individuals who are low-income or uninsured (HRSA, 2019). There are five parts within the Ryan White HIV/AIDS program: Parts A, B, C, D and F. The Ryan White HIV Provision of Care and Special Populations unit of EOHHS is the only direct recipient of Part B of the funding in the state. Part B of funding includes the AIDS Drug Assistance Program (ADAP) which provides FDA-approved medications to HIV positive individuals whose poverty level is 500 or below who have limited health coverage or do not have any coverage at all (HRSA, 2019).

Case managers play a very important role in distributing HIV care to patients. As members of a Ryan White care team, the roles of a case manager included assisting patients navigate the healthcare and social services system, providing essential education, following up with them to make sure that patients understand how important it is to keep their viral load suppressed. Another important role as a Ryan White case manager is to identify and address common medical concerns (such as adherence problems, substance abuse, and mental illness) and report back to other health care providers, such as doctor/clinician (Target HIV, 2020). 
There are challenges that case mangers often facing while distributing care to PLWHA. Those challenges are included: making sure clients take their medication daily, keeping their medical appointment and not falling out of care. Another challenge that case managers often experience is the high numbers of cases that often causes stress and burned out (Target HIV, 2020).

In 2017, the Ryan White unit of RI introduced an innovative way to enhance health behaviors via mobile health platforms to its clients, called TAVIE-HIV. TAVIE-HIV is a digital platform that is clinically validated and designed to help individuals with HIV to learn the skills required to manage their health conditions, such as managing the medications, medical appointments, learning how to self-monitoring and screening their own anxiety and stress on regular basis (360 Medlink Inc., 2019). The RI Ryan White Part B program partnered with 360 Medlink ( technology and software company that developed both of the platforms), beginning the process of developing and customizing TAVIE applications based on feedback and interviews that were gathered from the Ryan White Part B patients and case managers (360 Medlink, 2020). The interviews focused on what users wish to see on their mobile health platform that would help them with their HIV care and most importantly to help case managers with challenges they might be experiencing. For example, medical appointment reminders, HIV medication reminder, learn about mental health and learn how to manage them through the application (stress management course, etc.). If this method is effective, it would be helpful for both case manager and clients.

In September 2018, the RI Ryan White unit introduced the newest version of TAVIE platform to its clients, TAVIE-RED. The TAVIE-RED platform is also clinically validated and could be used to assist users in many different aspects of care/daily activities. For instance, TAVIE-RED provides access to social services such as location for food banks and clinics that 
specifically provide for PLWH in RI. TAVIE-RED provides evidence-based intervention for physical and mental health (360 medlink,2019). This includes decreasing and managing stress and increasing the number of physical activities such as exercising. After finishing each assessment, users will receive their personalized feedback (360 medlink,2019).

What makes TAVIE-RED platform different from its previous version is the gamification. Gamification is defined as "the process of adding games or game-like elements to something (such as a task) so as to encourage participation" (Merriam-Webster). The gamification portion associated with mobile health applications is not just designed for entertainment but with the aim of getting the users to engage with health care related activities/assessments on the application. For example, let us say a user monitors their disease symptoms and tracks their symptoms on the TAVIE-RED application. For each phase of the assessment that users complete on the application, they receive virtual and recursive rewards based on their completion. This is where the aspect of the gamification plays as the driving force in the mobile health application. The aspect of gamification will drive users to engage with all contexts in the application and make the experience enjoyable and promote better health outcomes.

According to 360 Medlink, Inc (2020), prior to the introduction of TAVIE, clients who are enrolled in the Ryan White program appeared to demonstrate lack of connectivity to the internet, lack of Smartphones, and lack of capacity to engage the healthcare team (both clinical and non-clinical team). This vulnerable population struggles and faces day-to-day challenges due to a variety of reasons. For one, $21 \%$ of the population reported being homeless/unstable housing. Secondly, 33\% reported having clinical levels of depression. Third, $50 \%$ failed to manage their HIV symptoms and reported that they need help to manage their symptoms. In 
addition, many of this population never owned a smartphone prior to TAVIE platforms being released. $20 \%$ reported that they never owned a cell phone before and up to $90 \%$ reported that they did not have a smartphone before (360 Medlink, 2020).

Because HIV is such a prevalent issue, technology could be used to make a change in this matter. In this case, the technology that is being referred to in this project is the usability of smartphone and mobile health applications (TAVIE-HIV and TAVIE-RED), which were specifically designed for this population (PLWHA). With the support of technology through a mobile health application, users could have easier access to community resources regarding the HIV care, such as the nearest HIV care facility, foodbank, and other resources related to HIV care. Most importantly, the application could be used to improve self-management for HIV medication, chronic diseases, emotional health, and monitor their medical appointment with health care providers.

\section{Literature Review}

\section{Mobile Health (mHealth)}

According to the Foundation for the National Institutes of Health (FNIH) (2012), Mobile health (mHealth) is defined as "the delivery of healthcare services via mobile communication devices". Mobile health applications have been used to assist patients in many aspects of healthcare. Mobile Health usually refers to the use of mobile devices or any wireless technology in medical care. MHealth could be used to educate users about preventive healthcare services and other health related issues. Some mobile health applications are used to assist patients with their daily routine diet, exercise, and medical appointment reminders. Mobile health applications are used to improve health outcomes through the delivery of medical health information. The mHealth applications continue to expand with thousands of them available on Apple iTunes and 
Google Play (Cho, et al., 2018). Mobile health can be considered as one of the advanced techniques to deliver care in the US healthcare system, however, getting consumers' attention and engagement can still be still challenging. A study conducted by the National University of Singapore found that gamification is effective in increasing users' attention in engaging in mobile health applications and encouraging both healthy (but lack exercise) and unhealthy people to maintain their health status (Lee et al., 2017).

University of Virginia researchers conducted a study of a mobile health application, called the Positive Links (PL) among newly diagnosed HIV patients at the UVA's Ryan White Clinic in 2018. The goals for this application were having the viral load suppressed, improve care coordination between health care providers and patients, and improve case management. Most importantly, the application was designed to support PLWH to connect with care, improve patient engagement and the overall clinical outcomes (Wicklud, 2018). The application was moderated closely by the clinic's staff. For example, their case manager/the clinic's staff would coordinate a medical appointment and send the reminder to users through the PL application. Providers at the clinic could also share health related info to their patients through the PL application. Users could receive tips about living with HIV from their providers and learn about how to interact with clinical services available at the clinic. Users can review self-reported data weekly and alert a notification about their upcoming appointments. The total sample for this study is 77 individuals who were identified as the recently- diagnosed HIV patients. The Positive Links application was introduced and provided to the participants by the clinic's staff and being observed for a year. After 12 months of using the application, the result of the study showed that the number of patients that have regular visits to the clinic increased from 51 percent to 81 
percent. Viral load suppression jumped $47 \%$ at the beginning of the study to 87 percent at six months to 76 percent after one year (Wicklud, 2018).

According to Cho et al. (2018), "more than 325,000 mobile health (mHealth) applications were available globally on Apple iTunes and Google Play in 2017, and the number of mHealth applications continues to increase" (p. 23). However, most of these applications are not offered for free. If they are, they are not provided with high-quality information, nor do they promote any interactive activities. For instance, an article, “A Mobile Health Intervention for HIV Prevention Among Racially and Ethnically Diverse: Usability Evaluation” (2018) introduces a mobile health application called MyPEEPs that is specifically designed for the HIV population, and primarily delivers HIV prevention information. In this case, the target population of the study are young men, MSM (men who has sex with men), between the ages 13 and 24.

Mobile health platforms have become more advanced every day, especially with the combination of gamification. With the advancement of technology, combining with mHealth gamification would be considered as one of the most advanced tools in the healthcare system since smartphones are commonly used and available to many people nowadays anyway. Therefore, downloading a mobile health application on their phones should not be a problem. Smartphones imitate what a computer can do, and with advanced software combined it can be an extreme support to the healthcare system. For example, mHealth applications and software on the phone can be used to assist individuals' daily routines, such as calorie counting, scheduling medical appointments, and to communicate with their providers. Many studies on mobile health gamification in different areas of care show how it could be used to improve the overall health of an individual. For instance, there is a study about using mobile health gamification for chronic disease management. An article, “A game plan: Gamification design principles in mHealth 
applications for chronic disease management" by Miller, Cafazzo, and Seto (2014) was conducted with a purpose to explore the gamification portion in mHealth applications, designed to help improve self-management. This mobile health app that they studied mainly focused on self-care management for chronic diseases such as diabetes. For example, MySugr Mhealth platform used for diabetes management that helps users keeping track of their blood glucose input as well as their daily diet and their overall dietary habits. Another article, "Using Mobile Health Gamification to facilitate Cognitive Behavioral Therapy Skills Practice in Child Anxiety Treatment: Open Clinical Trial," uses mHealth to focus on different areas of care such as mental and emotional health and child anxiety disorders. The study was conducted on an mHealth system called SmartCAT, specifically designed to enhance Child Anxiety Treatment. The results found that mHealth gamification improved patients' outcome and is a potential way to facilitate the cognitive behavioral therapy skills through the Smart CAT platform (Pramana et al.,2018).

One study, “A Mobile Health Intervention for HIV Prevention Among Racially and Ethnically Diverse: Usability Evaluation” was conducted among young men who are MSM (men who has sex with men) between the ages 13 and 24 (Cho et al., 2018). In the study, participants were introduced to a mobile health application that was specifically designed for HIV prevention and people who might be at risk of HIV. The mobile health application combined with gamification was supposed to keep users engaged and actively use the application. The findings of this study show that the sample group who used the platform were assessed to be at lower risk in getting HIV after they participated in the study, especially the sexual risk that may come with being under the influence of alcohol or drugs (Cho et al., 2018). According to the data reported, the outcomes show that participants successfully completed activities on the application with positive feedback. The result was evaluated by the mean scores rated by experts ranging from 0.4 
and $2.6(0=$ no usability problem to $4=$ usability catastrophe $)$. The overall study's standard deviation was 0.65 with an overall rate of post-study system usability questionnaire score of 1.63. This reflects that there was strong user acceptance of the mHealth application. However, there was also some feedback on how the features of the application were not interesting and the information is not high quality.

In 1965, Moore's law was proposed by Gordon Moore, the founder of Intel. Moore stated, "The number of transistors on a computer chip doubles about every 24 months" (Patrick, et al., 2008, p. 176). Technology has rapidly grown since then; thus, it has become an integral part of medical care. Combined with the fact that most people have access to a smartphone, there is a great deal of potential for these two modalities to intersect. With advanced technology support in the healthcare system, many support tools such as mobile health applications and software can be produced and serve consumers' needs appropriately. For example, many mobile health applications were created to assist individuals with their needs in and outside of care, such as keeping track of their medical appointments, etc. (Patrick et al., 2008, p. 178). However, one challenge that might occur with this advanced technology tool is that not all mobile health applications are free and available to everyone. If technology is used for health-related issues, it should be usable by everyone: the elderly, people with low literacy, as well as those with permanent or temporary disability (Patrick et al., 2008, p. 179). Therefore, the TAVIE-RED platform would be incredibly useful for this population as it is free with a high quality of information. Using this mobile health application to assist in delivering HIV care could help fill the gap in care and allow the patients to communicate more effectively with their providers. In addition, mHealth can be used to allow healthcare providers to communicate with each other about patients. 


\section{Specific Aims}

The focused for this project was to study the use of digital platforms in the care of PLWH. The aims for this project were: (1) to describe how people living with HIV use the two platforms, called TAVIE-HIV and TAVIE-RED, (2) to compare and contrast the use of the two platforms, and (3) to measure client satisfaction with the TAVIE-RED application. Clients' use of TAVIE-HIV was measured by their Health assessment completions. Clients' use of TAVIERED was measured not only by health assessments but also by quest completions. Quest is the gamification term that refers to a mission that a player may complete in order to gain a reward. Quest is a series of objective tailors around the clients' opportunities for growth in the application. Each quest contains health assessments and activities that relate to care. For example, one of the quests is to take a walk or do any kind of exercise the user prefers and record it to the application to earn XP points/reward. In this case, quests in TAVIE-RED contain a variety of health assessments such as emotional health and physical health assessment. Clients' use of the applications will be measured by users' quests and health assessment completions in the application. Client experience and satisfaction with the platforms will be measured through a survey that was distributed to TAVIE-RED users.

\section{Methodology}

A descriptive study was used to describe how PLWH use the platforms TAVIE-HIV and TAVIE-RED and how it supports users in various ways. The cohort for both TAVIE-HIV and TAVIE-RED are between the ages of 18-65+ in the RI- Ryan White program. The total participants of TAVIE-HIV are 131, which was distributed from 2017-September 2018. TAVIERED consists of 215 participants (September 2018-September 2019). The initial cohort that was exposed to both platforms consist of 47 individuals in total. Variables that were collected from 
individuals who enrolled for the programs and were used to described in this project included: gender, race, age, level of education, employment status, housing status, marital status, health insurance status, medication coverage status and their emotional health status. In the emotional health section of the questionnaire form, "Patient Health Questionnaire (PHQ-9)," assessment is required to be completed before the application is introduced.

\section{TAVIE-HIV Platform}

The TAVIE-HIV platform is the clinically validated mobile health application that was established by 360 Medlink, Inc. and the RI-Ryan White unit. This platform was released in 2017 prior to the TAVIE-RED edition. This platform contains health assessments and videos, along with a virtual nurse that would help and support users through their health journey. However, it does not have any gamification in the system like TAVIE-RED. According to 360 Medlink Inc., TAVIE-HIV is "the first clinically validated Virtual Nurse TM platform to help patients living with HIV learn the skills and self-efficacy to manage their disease and adhere to their antiretroviral therapy" (360 Medlink Inc., 2019).

TAVIE-HIV platforms provide video contents and assessments for users to complete. The baseline assessment of self-efficacy related to four aspects and barriers associated with HIV (to follow up the impact of the intervention on skill development motivation, quality of functioning and vulnerability to stress and depression.) There are 4 sessions that take place: (1) Medication Management, (2) Emotional and Management Assessment... etc. Session 1 contains HIV education, side-effect medication management and many more. Most importantly, it provides coaching and skill development for self-efficacy, which is needed to adhere and persist with their treatment. Session 2 provides emotional management and problem-solving skill development. Session 3 makes space for coaching, which promotes positive reinforcement to 
improve communication within the community, family and within their health care providers. Lastly, session 4, the review session, includes optimism, HIV knowledge, anxiety, and alcohol drinking assessment. Optimism is a life orientation test to assess optimism vs. pessimism in the HIV population. HIV knowledge is a self-reported assessment of HIV related knowledge. Anxiety assessment is a regular-basis screening and follow-up of anxiety and stress, with visual representation of results for empowerment and reinforcement of self-monitoring. Alcohol drinking assessment is a screening and identifying at risk alcohol drinkers. (Appendix A)

\section{TAVIE-RED Platform}

TAVIE-RED is the first mobile health platform that comes with gamification for the Ryan White unit. Prior to the implementation of any of the digital platforms, PLWH within the Ryan White program appeared to be unable to manage their poly conditions and disease such as psychological health and physical health (360 Medlink, 2019). Gamification in TAVIE-RED could be a turning point that interests or encourages this vulnerable population into engaging in health care through a mobile application. TAVIE-RED contains different contents and features in the application that would be the driving force for this whole new way of getting people into care. For instance, the platform consists of challenges through quests, virtue/recursive rewards system, entertainment through gaming such as spinning the wheel for rewards, decorating their avatar, puzzling, and many more.

Gamification is known as a process of using gaming to motivate users to engage in different areas that are usually non-gaming contexts. The gamification portion associated with mobile health applications is not just designed for entertainment but with the aims of assisting users in healthcare related areas; for example, maintaining their health status. This is known as "Serious Games". Serious gaming is known as participation in a type of game that is not simply 
used to entertain, however, its primary goal is to assist and support in areas such as healthcare and education. Martin and Shen (2011) define serious gaming as a mental contest that provides users a purpose in playing beyond entertainment purposes. Serious gaming is commonly used for corporate health, public policy, education and strategic communication objectives (p.944).

Gamification with serious gaming empowers users in their games to learn new skills.

Additionally, the knowledge from gaming is transferable to their daily lives and proves to be helpful on an everyday level.

In other types of games, players usually learn something in every game they play; however, not all the skills and knowledge they earn from that game is helpful in their real life. For instance, in "Super Mario Bros., the skills users learn from this game cannot be transferable into their real life. In this game, mushrooms are dangerous. However, if users can jump on them, those mushrooms turn into points which are what game players seek to earn. In addition, users also learn about the turtles in Super Mario Bros. Users learn that they can jump on turtles and use the shells to kill their enemies. Those are skills that users need in order to play and do well in the game. However, this skill and knowledge that users earn from playing this game are not useful and are not transferable into the real world. This is why serious gaming is such an important tool when it comes to combining gamification with mHealth. In a serious game, the knowledge and skills that users earn are useful for their real-life world. In other words, when the user learns something in the game, the knowledge is transferable to the real world, as the game is not designed for entertainment alone but also built with educational purposes.

\section{Leaderboard}

Leaderboard is a scoreboard showing players' current scores of the leading competitors on the application. This is where users can see their levels and experience points (XP) and get a 
sense of how well they are doing with the application as compared to their peers. The XP points are the points that users earn from completing each assessment/task on the application. Then these points are used to qualify a player's character's life experience and progression through the game. Leaderboard contains all TAVIE-RED users in the state of Rhode Island. Although users are able to see their peers' progress on the leaderboard, their identity and privacy are well secured because the username is unique and cannot be identified. Usernames are created based on the questions the user answers when they first register on the application. Those questions are: (1) what is your favorite animal? (2) what is your favorite number? and (3) what is your favorite color? An example of a username is Udhr08, and that is how it appears on the leaderboard. This means that users can be assured that their identity and privacy is well protected.

\section{Challenges and Quests}

Challenges through quests in TAVIE-RED are one of the essential keys to drive other gamification mechanics, in order to make sure the application is effective. Certainly, there are other essential keys that drive the gamification, such as the recursive reward system. However, quests are the main component for it to be effective because that is where all the challenges occur and keep the users engaged. TAVIE-RED's quests are divided into five main categories: Well-Being, Your Health, Sleep Insomnia, Meeting, and Red quests (Appendix B-F).

The Well-being quests. These quests guide users on their emotional health journey with different health assessments and activities that would benefit their health. One example of this is a quest that encourages clients to meditate with an actual meditation guideline on the app and would walk the user step by step on how to finish the quest (Appendix B). This quest category focuses primarily on users' well-being and it encourages users to look at more of the positive aspects of life. Some quests encourage users to calm their mind, reducing stress and anxiety by 
finding a comfortable environment. Then, the quest continues to guide users how to control their breathing and start a meditation quest (the quest would walk users step by step on how to practice meditation, complete the quest and earn the recursive rewards in the application).

The health quests. These quests, on the other hand, are focused on physical and overall health activities such as quests that have clients take a walk or exercise (Appendix B). The rewards include a Reddie ticket for spinning the wheel in the application, XP points, RED ticket for the monthly raffle ticket, and other items for the avatars. These mechanisms encourage clients to play with the game and challenge them to complete quests (physical health activities) to reach their milestones in the application. For those who are not familiar with the application, TAVIE-RED has a quest that teaches users how to play and earn points. For example, a pillbox quest is a quest where the user is introduced to the application and learns how to put in the medical appointment, appointment and medication reminders in the application.

The sleep insomnia quest. These are specifically designed to support sleep with different kinds of meditation styles. Users can practice meditating directly right from the application, as it is provided in the application itself with guidance and meditation music (Appendix C). There are other categories that focus generally on emotional health support. However, this quest category primarily focuses on mediation that helps with sleep insomnia.

The meeting quests. These quests are designed to encourage clients to attend their medical appointments with their providers, such as their medical doctors, nurses, therapists, and case managers. In order to complete this quest, users will have to attend a scheduled medical appointment. Take, for example, a meeting quest with a dentist; in order to complete this quest, the user will have to complete a visit with their dentist (see table 2.4). 
The red quests. This quest category is unique from any of the other categories on the application. It contains a variety of information that users will find helpful because it provides guidance on how to use the application, how to set appointments on the application, and educational quests on HIV pregnancy and how to take care of oneself while being pregnant (Appendix F).

After finishing each quest, the user receives rewards on the application such as XP points, red tickets, and level-ups in the game. XP points are the points users earn from completing each quest or assessment in the application. All of these components combined made game mechanics in TAVIE-RED effective. The system of XP points and levels are designed to keep the users aware of their level of engagement in the application and reward continued expertise. Users could earn their XP points by inputting their medications and taking them daily as directed. They could earn points from attending their medical appointment, complete a health assessment, or a quest on their TAVIE-RED application. Points and levels are intertwined with each other because as users earn their XP points, they level up in the game. The higher their levels are, the more chances they will get from receiving their recursive rewards.

\section{Setting, case selection and sample}

This project was conducted by using a descriptive study. The aim of using this method is not only used for describing the two platforms, but to develop deep understandings of how this vulnerable population perceive their social realities and how the platforms can be used to support them daily. The total users of TAVIE-HIV were 131 people in (September 2017-2018) while the total number for the TAVIE-RED platform is 215 participants (September 2018-2019). The age demographic of both groups were ages 18 to 65+ (Appendix G). 
TAVIE-HIV was released prior to TAVIE-RED platform. The main difference between the two is that TAVIE-HIV does not include gamification while TAVIE-RED does. This would be interesting to observe, especially the group that were exposed to both platforms.

Variables that were analyzed from TAVIE-HIV include gender, race, age, level of education, housing status, physical health report, emotional health report, employment status, and health assessment completions. Those health assessments include emotional health assessments on depression and HIV education.

Variables from TAVIE-RED that were analyzed include gender, ethnicity, age, level of education, housing status, and employment status. TAVIE-RED's variables that we are going to look at are the same as TAVIE-HIV's. The only difference is the quest of gamification in TAVIE-RED. In gaming, "quest" is known as a mission or a task that players have to complete in order to gain a reward and move on to the next level. Quest in TAVIE-RED works the same way, users must complete quests in order to gain recursive rewards and move on to the next level. (Figure 2)

To be enrolled for TAVIE-RED, participants have to contact their case managers/agency to make sure that they are Ryan White clients and qualify for the program. Then, the agency's staff (case manager) would contact the Ryan White unit for an enrollment. When the enrollment time arrived, participants were asked to complete a questionnaire form prior to the application introduction. The form consists of several main categories: demographics, physical health history and emotional health categories. The following is the data that was collected from the questionnaire form during the enrollment process:

1. Demographic: This section collected information such as gender, ethnicity, age, level of education, employment status, housing status, and health insurance status. 
2. Health History: This includes questions on their HIV care. For example, some of the questions are:
a. Have you been diagnosed with HIV?
b. Are you currently taking HIV medication?

c. During the past two weeks, did you miss doses? If you missed doses, what do you think is the reason?

d. Physical Health: This section asks participants to fill out their lab results. For example, those lab results include their CD4 count and viral load.

e. Emotional Health: In this final section, users are asked to rate from 1-4 scales how often have they been bothered by the following questions. For instance, one question asks, "How often do you feel depressed and/or worthless?" The form provides an answer key with a scale of 1-4 (1= not at all, $2=$ a few times a day, $3=$ several times a day, $4=$ nearly every day $)$, which users would choose to best describe their situation.

After the questionnaire form was completed, participants were provided an android phone preloaded with the TAVIE-RED application. The instructions were given on how the application works, and the gamification concept was introduced. During the enrollment process, participants were also asked to sign the HIPAA consent form to enable the EOHHS to have access to their information as provided in the evaluation forms they complete. Then a phone was issued with the application installed. Step-by-step instructions were provided on how to use the application was performed. The application consists of many different quests that are mainly designed to support both physical and emotional health. Each tutorial provides a step-by-step guide on how to complete the quest. For example, a quest on emotional health included a meditation quest that guides users on how to meditate, step by step. After the group enrollment, TAVIE support 
sessions were provided and facilitated by the RI-Ryan White unit and their case managers. The TAVIE support group is a group that allows users to question and voice their concerns about the experiences with the TAVIE application, technology, smart phone and any other TAVIE-related problems. This allows users to feel more supported by the Ryan White staff, as well as by their case managers during the support group session.

The application is divided into five main "quests categories:" well-being, emotional health, meeting quest, sleep insomnia and red quest. Each quest contains between 5-9 activities and each time a user completes a quest, he or she would earn different rewards in the application: red tickets, reddies, accessories, and XP points. Each group enrollment consisted of about 20 people; the estimated total sample population consisted of about 215 people (Appendix H). As mentioned, after the enrollment is conducted, a follow-up session was provided at least twice after the enrollment date. During this follow-up session, application tutorials and other application assistance were provided as needed. After finishing each quest, the user receives rewards on the application such as xp points, red tickets, and level ups in the game.

In August 2019, satisfaction surveys were distributed to the users by 360 Medlink, Inc (2020). Those surveys were related to accessibility and interactivity in using the application. The survey was used to ask what they like or dislike about the application. In addition, the goal of the survey was to see how helpful the users thought the application was. For instance, some of the questions asked if the users find TAVIE-RED was helpful to manage their health condition, to take their medication. The results of the survey were then collected and analyzed by the 360 Medlink, Inc. and shared with the RI-EOHHS, the Ryan White unit. 


\section{Statistical Approach}

Descriptive analyses for this project were conducted to describe how people living with HIV use the two platforms TAVIE-HIV and TAVIE-RED, comparing and contrasting the use of the two platforms, and measuring client satisfaction with the TAVIE-RED application. It is used to describe demographic characteristics of the full sample as well as the application specific respondent characteristics. Demographics for both platforms included gender, race, age, education, employment status, housing status, marital status, health insurance, medication coverage, HIV risk factors, and victim of domestic violence. The data were analyzed using SPSS statistical software and Microsoft Power BI. SPSS software is known as a software package used for statistical analysis. Specifically, this software is helpful for this project to analyze and break down the demographic data for both platforms. Microsoft Power BI is an advanced tool that gives an interactive visualization for this project data to display. In addition, it shows relationships between variables.

One of the aims for this project was to compare the differences between TAVIE-HIV and TAVIE-RED and how users respond differently to each of them. In this case, Power BI would make the process of the data analyses a lot easier. For instance, clients' use of TAVIE-HIV was measured by the Health assessment completions while clients' use of TAVIE-RED were measured by quest completions. Power BI shows interactive data between the two by linking both platforms' relationship by the users' identifier. SPSS statistical software was used to analyze and break down all variables and compare them from one platform to another. 
Results

\section{TAVIE-HIV Demographics}

For the TAVIE-HIV version, a description of participants' demographic data for the TAVIE-HIV version can be found in Appendix A. For gender, more than half of the participants are male $(58.01 \%)$ while there are only $39.69 \%$ of females. Some people refused to answer the questions leaving the questions blank. For race, the highest percentage of participants are White (31.29\%) while the lowest rate was American Indian (<10\%). (Appendix G)

The range of the participants are 18 to 65 years old. According to the data collected from the questionnaire forms, the majority of the participants were 45 years and older $(32.06 \%$ were between 45 to 54 years old, and $37.49 \%$ of them are between $55-64 \%$ ). The majority of participants are high school graduates $(45.04 \%)$. The data showed that only 12.40 percent of TAVIE-HIV users were employed and up to 82.17 percent were unemployed. The majority of them had permanent housing (either rent or own), however there were about 10 percent who are homeless and about 12 percent that are in temporary housing. This refers to shelter or any other kind of temporary housing. Finally, while looking at the participants' marital status, the data showed that about 57 percent out of the total users were single or never married, and about 10 percent are married, widowed or divorced.

In the questionnaire, individuals were asked about HIV risk factors that may apply to them and here are the responses: 37 out of 131 individuals $(24.42 \%)$ reported MSM (men who have sex with men), 37 (28.24\%) reported intravenous drug use, $<10 \%$ reported alcohol abuse, $<10 \%$ reported hemophilia/coagulation disorders, 38.93\% reported heterosexual, one person $(0.76 \%)$ reported mother with HIV and $<10 \%$ people reported receipt of blood 
transfusions, blood components or tissue. Most of the participants reported having Medicaid as their health insurance and their medications are fully covered.

\section{TAVIE-RED Demographics}

Variables that were collected for TAVIE-RED versions were gender, race, age, education level, employment status, housing status, marital status, health insurance, medication coverage status. This group, there were $134(61.75 \%)$ males, $75(34.56 \%)$ females, and $<10 \%$, transgenders. The racial group that had the most participants were White $(32.72 \%)$, the second highest group of participants were Black (26.27\%) and the racial group with the least participants are Asians $(<10 \%)$. The findings were interesting because black people were usually most stigmatized with having HIV/AIDs, however, the result for this population showed otherwise. The age range for this project was from the age of 18 to 65 and older. However, it was noticeable that the highest age group for this project was 55 to 64 years old $(36.5 \%)$. On the other hand, the age group with the lowest participants ranged from 18 to 24 years old $(<10 \%)$. (Appendix $\mathrm{H})$

The study also evaluated participants' education status. The majority of participants for this project are high school graduates (45.83\%) and 64 individuals $(29.63 \%)$ were less than high school or no diploma. There was 178 out of 215 individuals $(82.03 \%)$ were unemployed and only about 13 percent were employed. 141 out of 215 individuals $(65.28 \%)$ are in permanent housing, 49 individuals $(22.69 \%)$ are in temporary housing and 19 individuals $(8.80 \%)$ are homeless. Most of this population was single and only about $8 \%$ were married, and approximately $18 \%$ are divorced or separated. For health insurance status, there are 135 individuals (62.21\%) who state that they were under Medicaid and 199 individuals (91.71\%) report that their medication was covered. One of the questions in the questionnaire form also asked individuals about situations that may apply to them. 64 individuals (29.49\%) reported 
experiencing MSM (men who have sex with men), 29 individuals (13.36\%) reported "intravenous drug use", 15 individuals (6.91\%) reported "alcohol abuse", $<10$ individuals reported "hemophilia/coagulation disorders," $<10$ individuals reported "receipt of blood transfusions, blood components or tissue," 25 individuals (11.52\%) reported "mother with HIV," and $84(38.71 \%)$ reported as "heterosexual." Another important question that was asked in the questionnaire form was "during the past 6 months, were you a victim of domestic violence?" The results show that 16 individuals $(7.37 \%)$ reported "yes" to a victim of domestic violence and 18 individuals $(8.29 \%)$ left the answer blank or refused to answer.

The findings of this project revealed that gamification in TAVIE-RED platform promotes better outcomes in users' engagement with the application. The results from the survey $(\mathrm{N}=82)$ also reveals that $77 \%$ of users actively engage with the application, $80 \%$ agreed that TAVIERED platform helps them manage their medication, and $82 \%$ said it helps manage their health condition, and $88 \%$ of the users stated that they would recommend the application to others. The findings also reveal that up to $90 \%$ of the users for both TAVIE-HIV and TAVIE-RED are depressed according to the PHQ9 scale (Appendix I)

According to the data collected from the evaluation/questionnaire that were distributed to the clients when they first enrolled in the program, they were asked to complete a PHQ-9 with the enrollment form. There are five levels on this scale: none, mild, moderate, moderately severe, and severe. After the data analysis, the severity levels with the highest numbers are "severe" $(29.8 \%)$ and "moderately severe" $(29.8 \%)$. This means that over 60 percent of the participants are experiencing severe depression. (appendix $\mathrm{J}$ )

On the other hand, the data on depression severity levels on TAVIE-RED showed that 99 individuals (46\%) reported "severe" on the depression scale and there were $47(21.9 \%)$ 
individuals who reported "moderately severe" and only less than 10 individuals reported "none" or not depressed. Appendix J shows the crosstab analysis on different variables and the depression severity.

\section{TAVIE-HIV: Depression severity}

The data revealed the number of people who have been struggling with their own emotional health and also the severity of the individual's situation is by using the PHQ9 scale to determine their depression severity from mild to severe broken down by demographics data. After running the data analysis in SPSS to cross-tap between gender and depression severity, the results show that men (73 individuals or $55.72 \%$ ) are more depressed than women (48 individuals or $36.64 \%) .21$ men (16.03\%) reported "severe" on the depression severity scale, while 17 women (12.9\%) also reported "severe." The top three racial groups that reported having depression are Black (33 individuals or 25.19\%), Hispanic (33 individuals or 25.19\%) and White (32 individuals or $24.42 \%$ ). These top three groups are also the highest number of participants in the project, so it makes sense that they also ranged as top three in having depression. (appendix K)

Different age groups were also looked at on the depression severity scale. The data of this project revealed that the top age groups that highly experience depression are 55 to 64 years old (48 individuals or $36.64 \%$ ), 45 to 54 years old (40 individuals or $30.53 \%$ ), and 25 to 44 years old (30 individuals or $22.90 \%$ ). This showed that the older population is more likely to experience emotional health challenges. Young people were also at risk of having depression, however, being compared to the older population (55+) they are still doing much better.

The results also showed that people with less than a high school diploma (38 individuals or $29 \%$ ), high school graduates (57 individuals or $43.51 \%$ ) and individuals with a bachelor's 
degree (30 individuals $22.90 \%$ ) have the highest report of depression severity. The majority of the individuals who reported experiencing depression in this group are people who are unemployed (103 individuals, 78.62\%) and only 15 employed individuals (11.45\%) reported on depression. There were 36 unemployed individuals $(27.48 \%)$ who reported "severe" on the depression scale, while there were only a few employed individuals $(<10)$ who reported in this same way. There were 28 individuals (21.37\%) of employed participants who reported on "moderately severe" while there were only a few unemployed individuals $(<10)$ who reported as such. The highest group of participants who reported experiencing depression is the group who are in permanent housing (78 individuals or 59.54\%), 15 individuals from temporary housing (10.68\%) and 14 individuals who are homeless or unstable housing (10.68\%).

\section{TAVIE-RED: Depression severity}

According to the data analysis of TAVIE-RED, men (131 individuals or $60.93 \%$ ) were more depressed than women (72 individuals or 33.48\%). Again, men were still in the lead for having depression compared to women. Racially, the data showed that the top three racial groups on TAVIE-RED who reported experiencing depression are still Black, Hispanic and White. These three groups were also the highest in TAVIE-HIV in the depression severity section. The data further reveals that 56 of the African American participants (26.04\%), 59 (27.44\%) of Hispanic participants, and 71 of white individuals (33.02\%) reported experiencing depression. White participants were the highest number who reported depression. There were 42 out of 71 white participants that reported "severe" on depression severity, 23 individuals of Hispanic participants (10.69\%) and 18 black individuals (8.37\%).

Looking at age, the age group who reported having depression were 55 to 64 years $(75$ individuals or $34.88 \%)$ and $40(51.94 \%)$ of them reported "severe" on the depression severity 
scale. The second highest group who reported having depression were in the age group 45 to 54 (58 individuals or $26.97 \%$ ) and 28 of them (45.90\%) reported "severe" on the depression severity. The age group who reported the least individuals experiencing depression is the 18 to 24 age group $(<10)$. This study also shows that the highest number of participants who reported experiencing depression were participants with a high school diploma (99 individuals or 46.04\%) and 48 of them (48.48\%) reported "severe" on the depression severity scale. The majority of the participants were in permanent housing, but this population has the highest report on depression severity. For TAVIE-RED clients, there were 137 individuals $(63.72 \%)$ who were in permanent housing and reported having depression and 58 of them (42.33\%) reported "severe" on the depression severity scale. The least number of individuals who reported experiencing depression were homeless or unstable housing (19 individuals or $8.83 \%$ ) but 14 out of $19(73.68 \%$ ) reported "severe" on the depression severity (appendix L).

\section{Initial cohort- TAVIE-HIV and TAVIE-RED}

According to the data analysis of both TAVIE-HIV and TAVIE-RED, the findings show that there were a total of 47 users who were exposed to both platforms. One of the analyses that was run for this group was viral load suppression. While they were using TAVIE-HIV, there were only 17 out of 47 individuals (36.17\%) who had viral load suppressed. However, after TAVIE-RED was introduced to this small group, there were 35 out of 47 individuals (74.46\%). The analysis was broken down further to their demographic information such as gender, race, age, education, employment status, and housing status. (appendix E)

Gender. Data revealed that before participants were introduced to TAVIE-RED and were still using TAVIE-RED, there were only $38.09 \%$ of women, $36 \%$ of men were viral load 
suppressed, then after they got exposed to TAVIE-RED, there were 15 out of 21 women (71.42\%), 19 out of 25 men (79\%) became viral load suppressed.

Race. Looking at viral load suppression by race, the viral load suppression rate improved in all races after clients started using TAVIE-RED. For example, while they were still enrolled in TAVIE-HIV, there were $50 \%$ of African, $<10$ out of 13 Hispanic, $35.29 \%$ of White, and $<10$ out of multiracial were viral load suppressed. Then after they were introduced to TAVIE-RED, there were 10 African, 13 White, and $<10$ multiracial became viral load suppressed.

Age. The most viral load suppression improved for age categories was the 55-64 age group (17 individuals). While using TAVIE-HIV, $<10$ out of 17 individuals were viral load suppressed and after they enrolled in TAVIE-RED, 15 out of 17 became viral load suppressed.

Education. The highest viral load suppressed rate for this group was the high school graduate (26 individuals). There were 8 of 26 participants $(30.76 \%)$ that were viral load suppressed during the TAVIE-HIV version, then after TAVIE-RED released and introduced to the group, there were 18 out of 26 high school graduates $(69.23 \%)$ that became viral load suppressed.

Employment status. The highest viral load suppressed rate for this group was unemployed individuals (38 individuals). Before TAVIE-RED, there were only 14 out of 38 individuals that were viral load suppressed (36.84\%), then after TAVIE-RED exposure 28 out of 38 individuals became viral load suppressed (73.68\%).

Housing status. Before TAVIE-RED, there were 14 out of 36 people (38.88\%) who were in permanent housing that were viral load suppressed. After TAVIE-RED exposure, 25 
individuals became viral load suppressed (69.44\%). Temporary housing individuals $(<10)$, before they got exposed to TAVIE-RED, there were only $<5$ out of 9 individuals were viral load suppressed, then after the exposure there were $>5$ out of 9 individuals were viral load suppressed (appendix M)

\section{TAVIE-HIV Engagement}

The data showed that from session 1 to session 4, the number of completions went down. As shown on the table for TAVIE-HIV engagement graphs below, there were $21.28 \%$ of the users that completed session 1 , however, as the sessions provided, there were fewer users that fully completed any session. For instance, there were only $8.51 \%$ of people who completed session 3 and $0 \%$ of people completed session 4 . (figure 4 )

The results revealed that the number of assessment completion also decreased. Assessment 1, "Views on HIV Treatment", there were only $2.13 \%$ of the users completed. Assessment 2, “Consequences of HIV," there were $14.89 \%$ completed. Lastly, assessment 3- "Control HIV symptoms" there were only $4.26 \%$ of the users completed. The rest of the assessments that are not listed means they are $100 \%$ incomplete and they were not touched by the users at all

The graphs (appendix E) show the breakdown of each variable and the users' engagement with TAVIE-HIV through their sessions and assessment completions. The findings show that in each variable the most completion was the beginning of the sessions. For instance, it is obvious that the most sessions completed were session 1 and assessment 1 , as it is the trial for the TAVIE-HIV users to see whether they like the application. However, as the sessions go down, the fewer people completed any sessions or assessment. This showed that users lost their interest in engaging with the applications after their trial with the first few assessments/sessions. 


\section{TAVIE-RED Engagement}

The findings for TAVIE-RED engagement can be found in appendix F. Although the findings show that males completed more quests (261 quests completed) than females (251 quests completed), the outcome of their experiences were interesting as female users have a higher number of experiences. Users' experiences in the application were not only the number of the users' logging into the applications, but it also counted toward their overall activities within the application itself. In this case, although females had a lower number of quests completed (251) than males (261). Female users (59,683 experiences) ended up earning more numbers of experiences than men $(29,193$ experiences). This showed that although one gender completed more quests than other users, it did not mean they would earn more points or experiences. On the other hand, all other variables such as race, age, education, employment status, and housing status show that the more quests completed, the higher the number of the users' experiences are. For instance, in the race category, the White population completed the most quests (286 quests completed) and they earned the most experiences in the application (58,700 experiences).

\section{(Appendix F)}

\section{Discussion}

Although there are thousands of mobile health applications available globally, those applications are usually not offered for free, but if there are, the quality of the information is not reliable. Additionally, users tend to lose their interests in using the applications after a while. In this project, TAVIE-HIV is a regular mobile health application just like one of those applications out there, but it was offered for free with high quality information. However, it still did not hold users' attention for long. The result shows that TAVIE HIV's users no longer engage with their application after completing a few assessments. There are a variety of reasons why users are no 
longer interested in the application. One, the application might be boring or too much for them to follow. Secondly, users might be struggling with their emotional health (stress/depressed) and unmotivated to do things in their daily life.

Another mobile health application that is similar to TAVIE-HIV is called Positive Links that was conducted by the University of Virginia. This application is also designed specifically for PLWH. This study reveals that 6 months after users started using the Positive Links application, users' viral load suppression increased from $47 \%$ to $87 \%$, however after a year of using the application, the viral load dropped from $87 \%$ to $76 \%$ (Wicklud, 2018). Although $76 \%$ is still considered a big improvement from the baseline, the question is: what caused the percentage of their viral load suppression decreased? If the University of Virginia continued their study for 2 years, what would happen then? Would the number of the Positive Links application keep decreasing? According to Wicklud's (2018) findings on mHealth application usage among PLWH, if the application does not keep the users interested, they will no longer engage with the application, and their health outcomes would go down as well. This is important to note because a mobile health application alone is not going to keep users interested in long. An incentivizer like gamification keeps users interested and reinforces users to interact with the health-related topics/activities on the applications.

TAVIE-RED application, on the other hand, was different from an ordinary mobile health application. It is offered free to the users with high quality information that is clinically validated. In addition, it comes with gamification that does not only entertain users but challenges them to complete quests and achieve their personal goals. According to the findings of the initial cohort of this project (the group that got exposed to both platforms), their engagement in TAVIE-RED is much higher compared to TAVIE-HIV (360 Medlink, Inc., 
2019). Their viral load suppression improved (36.17\% to $74.46 \%$ viral load suppression), and their engagement level improved across the board (appendix M). For example, one of the assessments that were introduced on TAVIE-HIV, less than 5\% of the users completed. However, once the same assessment was introduced on TAVIE-RED, up to $80 \%$ of the users completed it (360 Medlink, Inc., 2019). This shows that although both platforms are clinically validated, developed by the same organization, delivered by the same agency, and serve the same population, it does not mean the outcome will be the same.

Additionally, gamification is key for TAVIE-RED to be more successful than its previous version. TAVIE-RED's engagement data showed that male users completed quests up to 261 quests (29,193 app experiences) and female users completed quests up to 251(59,683 app experiences) (appendix F).It means that gamification on TAVIE-RED is a driving force on the application. It showed that no matter how helpful a mobile health application like TAVIE-HIV might be, if it does not have a mechanism like a serious gaming that would catch the users' interest and keep the ritual going, it still would not successfully get the users to engage with the application. For example, one thing that this project and the previous studies have in common are the users' interactivity. If the application does not have a driving force such as gamification to challenge them on the application, the engagement level tends to decrease. For example, MyPEEPs application from a previous study (Cho et al., 2018) and TAVIE-HIV got users engaged with the application at first, however, after a few assessments were introduced, the engagement level decreased dramatically. This shows the users' loss of interest during the process and that they no longer wanted to engage with the application. However, if there were to be a gamification like in TAVIE-RED, which is a driving force that keeps users interested in the 
application, their engagement level would be increased and better health outcomes would improve as well.

Overall, it is agreed that not every mobile health application out there would be helpful to the community and not all good quality mobile health applications out there are successful in getting people's interests especially among vulnerable populations like PLWH. This project aims to describe how PLWH react to the two platforms (a regular mHealth app vs. a mHealth app with gamification) and look at the usability of the platforms. This study supports the original aims of this project. For one, the findings of this study revealed many differences between the two platforms (TAVIE-HIV and TAVIE-RED). For example, different features with TAVIE-RED and its gamification that was used to challenge users and keep them interested. Secondly, it showed how users react to both platforms so differently according to their engagement data with both of the platforms (Appendix F). Thus, discussing the results of previous studies becomes important because it brings out the differences, common and uncommon results between this project and the previous study. It is important not to leave previous studies out of this discussion because it can add to the importance of this project and of mobile health applications at large.

\section{Limitations}

A small percentage of this vulnerable population are 65 years and older. Prior to the Ryan White program releasing these platforms to the PLWH community, many of the participants were not familiar with smart phones and some did not even own a smartphone before. Many of them got better over time after participating in follow up sessions with their case managers/EOHHS staff. However, a small percentage of this group may have limitations due to their age and unfamiliarity with a smartphone/gamification in the applications. The data showed that $6.5 \%$ of TAVIE-RED's participants are 65 and older and their engagement data are the 
lowest compared to other age groups. Additionally, because TAVIE-HIV and TAVIE-RED are designed specifically for PLWH in Ryan White program and RI is the first state trying this new innovative way (through mHealth application), the applications are currently only used by the RI Ryan White Part B program's patients. If these platforms are available to everyone who are HIV positive in the United States, it would be helpful to other PLWH into managing their HIV symptoms, care and medication.

Another limitation found in this project is availability of the application. The application is only supported by android. This means that any other device like the iPhone, it does not support the application. In addition, not all PLWH are qualified to get the phone or the application. Rhode Island is the first and only state that has these advanced digital platforms to support PLWH and one has to be the RI-Ryan White unit in order to qualify for the application. If the platforms were to be available for all PLWH in the country, the number of viral load suppression would be higher as the result already showed that the initial cohort that got exposed to the platform improved their viral load suppression and the game mechanism in TAVIE-RED has driven users to interact with mobile health application (the more interactive they are with the application, the more involved they are with their healthcare as all the quests in the applications are the health assessment that are designed to support the users with their medication adherence, medical appointment, care plan and promote healthier lifestyle).

\section{Conclusion}

With this project revealed that gamification is the driving force for the users' engagement. With the TAVIE-RED platform, users earn positive benefits from using it. For instance, users improved on self-managed care such as monitoring symptoms and receiving treatment reminders through the application. Users also have access to social services such as 
locating food banks and clinics. Most importantly, each quest in the application serves its purpose in promoting mental and physical health. The data showed that female $(n=21)$ completed up to 251 quests in total with at least up to 30 quests completion for each quest category (appendix N) (meeting quests (38), physical activity quest (40), health quests (80), well-being quests (64), and red quests (48). Male users completed up to 260 quests in total with up to 20 quests completion for each quest categories (appendix N) (meeting quests (49), physical activity quest (34), health quests (70), well-being quests (63), and red quests (44).

The result overall showed that there were major differences in the level of engagement between TAVIE-HIV and TAVIE-RED platforms. This study also showed the differences between the two platforms and how the gamification affects the users' engagements. The initial cohort group ( $\mathrm{N}=47)$ who got exposed to both platforms have completely different levels of engagement to TAVIE-RED compared to TAVIE-HIV (Figure 5-7). After the initial cohort got exposed to both platforms, it is concluded that gamification on TAVIE-RED has a major impact on clients' engagement. People who barely completed any assessments in TAVIE-HIV have shown significant improvement on TAVIE-RED. The majority of them reached levels 10 and above, some even reached levels 40 and completed more than 20 quests (20+ assessments). If we compare that to TAVIE-HIV, less than 10 percent of participants completed any assessments or questionnaires'

According to 360 Medlinks's survey collected in 2019, there were $82 \%$ of the users reported that TAVIE-RED helped them manage their health condition, $80 \%$ said it helped them take their medications, and $88 \%$ of the users said they would recommend TAVIE-RED to other people. This shows that using gamification as the driver in mobile health applications helps healthcare professionals in diagnosis and most importantly, engaging patients to involve in better 
health outcome behaviors. Gamification in the TAVIE-RED application uses challenges through quests, achievement XP points, recursive rewards, and mastery levels to keep the users engaged and stay motivated in completing their quests and goals. The TAVIE-RED mobile application may fill the gaps and the needs for consumers since the application is uniquely designed for vulnerable populations and is free, clinically validated, entertaining, and most importantly it combines gamification. In addition, using this mobile health application could help fill the gaps in care and allow the patients to communicate more effectively with their providers. Mobile Health platforms could be used to allow healthcare providers to communicate with each other about patients. This study focused on patients' perspectives and how they use these digital platforms to assist their daily activities and inspire them to achieve their daily goal (such as exercising, meditation, monitor their HIV symptoms and medication, and communicate better with their case manager through the TAVIE application). Further research is suggested on case managers' perspective of the TAVIE application, and to investigate the tools they use to interact with their clients (TAVIE's users) through the TAVIE applications. This would allow TAVIE's developers and providers to see both users and providers' perspectives. Most importantly, it would allow them to see if there are any gaps and if any improvements are needed for the future development of the digital platform. 


\section{References}

AIDs.gov. (2019) Who is at risk for HIV? Retrieved from https://www.aids.gov/hiv-aidsbasics/prevention/reduce-your-risk/who-is-at-risk-for-hiv/

AIDsVu. (2017). Mississippi. Retrieved from https://aidsvu.org/state/mississippi/

Breskin, A., Adimora, A. A. \& Westreich, D. (2017). Women and HIV in the United States. PLOS ONE, 12(2). doi: 10.1371/journal.pone.0172367

CDC. (2016). Pennsylvania- 2015 State Health Profile. Retrieved from https://www.cdc.gov/nchhstp/stateprofiles/pdf/pennsylvania_profile.pdf

Cho, H., Powell, D., Pichon, A., Thai, J., Bruce, J., Kuhns, L. M. \& Schnall, R. (2018). A mobile health intervention for HIV prevention among racially and ethnically diverse young men: usability evaluation. JMIR mHealth and uHealth, 6(9), e11450. doi:10.2196/11450

Gamification. (n.d.) in Merriam-Webster's collegiate dictionary. Retrieved from https://www.merriam-webster.com/dictionary/gamification

HRSA.gov (n.d). About the Ryan White HIV/AIDS Program. Retrieved from https://hab.hrsa.gov/about-ryan-white-hivaids-program/about-ryan-white-hivaidsprogram

Lee, C., Lee, K., \& Lee, D., (2017). Mobile Healthcare Applications and Gamification for Sustained Health Maintenance. Retrieved from https://www.mdpi.com/2071$1050 / 9 / 5 / 772$

Martin, M., Shen, Y., (2011). Defining and Leveraging Game qualities for Serious Games. Retrieved from https://ntrs.nasa.gov/archive/nasa/casi.ntrs.nasa.gov/20110012076.pdf Miler, A., Cafazzo, J., Seto, E., (2014). A game plan: Gamification design principles in mHealth 
applications for chronic disease management. Retrieved from https://journals.sagepub.com/doi/abs/10.1177/1460458214537511

Mobile health(2012) retrieved from https://www.himss.org/definitions-mhealth

Nhavoto, J., Gronlund, A. \& Klen, G. (2017). Mobile health treatment support intervention for HIV and tuberculosis in mozambique: perspectives of patients and healthcare workers. PLOS ONE, 12(4), e0176051. doi: 10.1371/journal.pone.0176051

Pramana, G., Pramana, P., Lomas, J., Lindhiem, O., Kendall, P., \& Silk, J., (2018). Using Mobile Health Gamification to Facilitate Cognitive Behavioral Therapy Skills Practice in Child Anxiety Treatment. Retrieved from https://www.ncbi.nlm.nih.gov/pmc/articles/PMC5968217

Rhode Island Department of Health. HIV progress (2019). Retrieved from https://health.ri.gov/programs/detail.php?pgm_id=10

Wicklud, E., (2018) mhealth Application for HIV Patients Prove the Value of "Warm Technology". Retrieved from https://mhealthintelligence.com/news/mhealth-app-forhiv patients proves-the-value-of-warm-technology

360 Medlink (2019). Retrieved from https://360medlink.com/?s=TAVIE+RED

360 Medlink (2020). Patients Centricity a Paradigm Shift. Retrieved from https://360medlink.com/wp-content/uploads/2019/02/TAVIERED_CaseStudy_3_2019.pdf 
Appendices

\section{Figure. 1}

Newly Diagnosed Cases of HIV

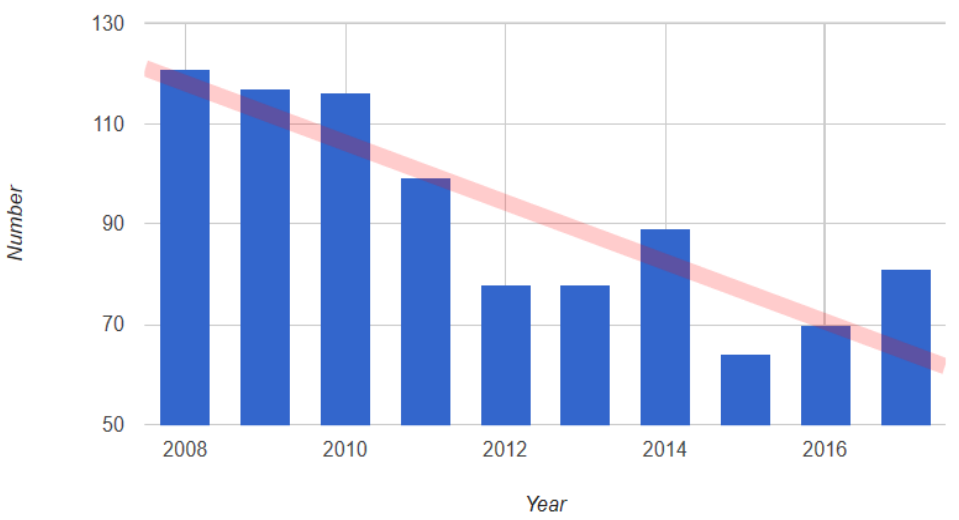

Note. The overall newly diagnosed HIV infections decreased.

Earn rewards as you play

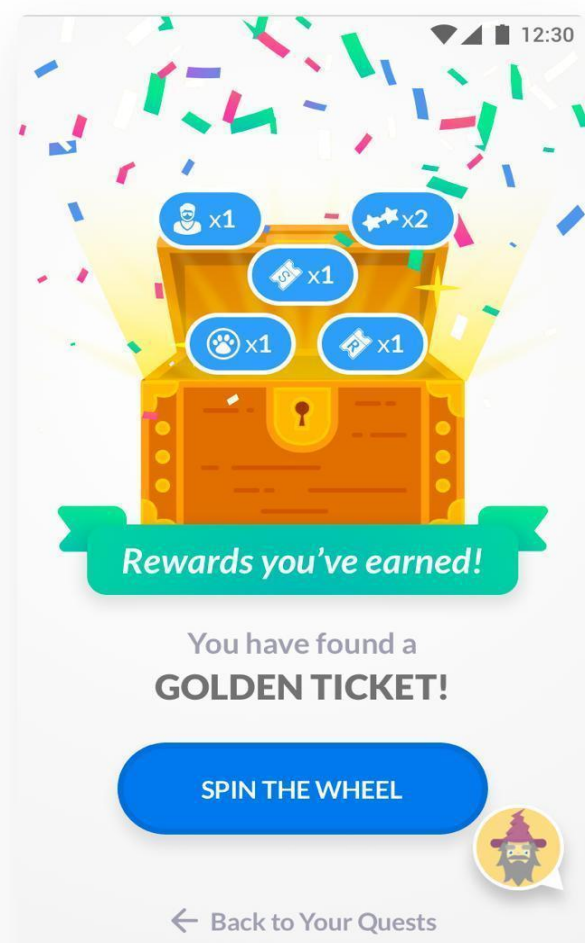

Figure 2: Earning rewards after a quest completion
Engage in quests to manage your health

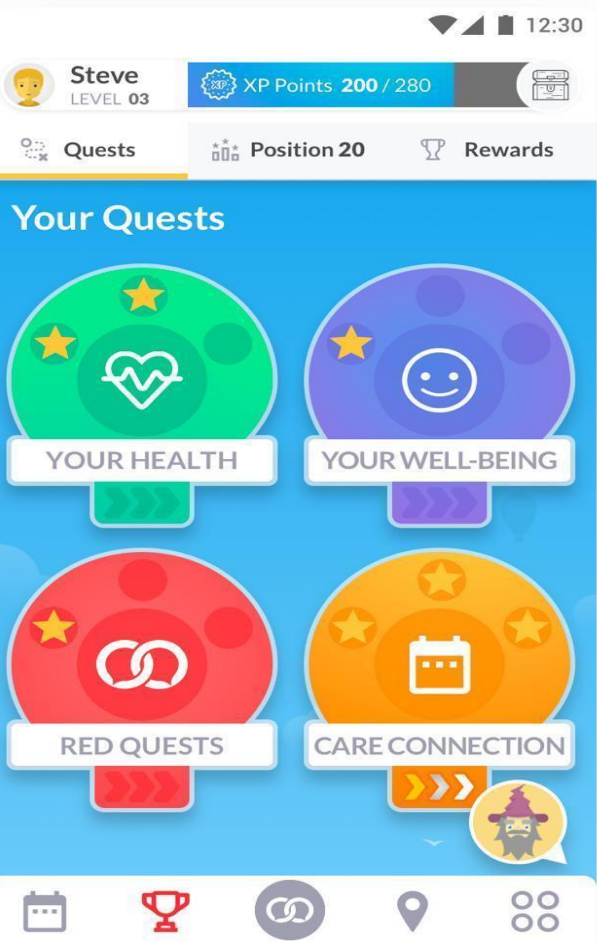

Figure 3: Quest categories 


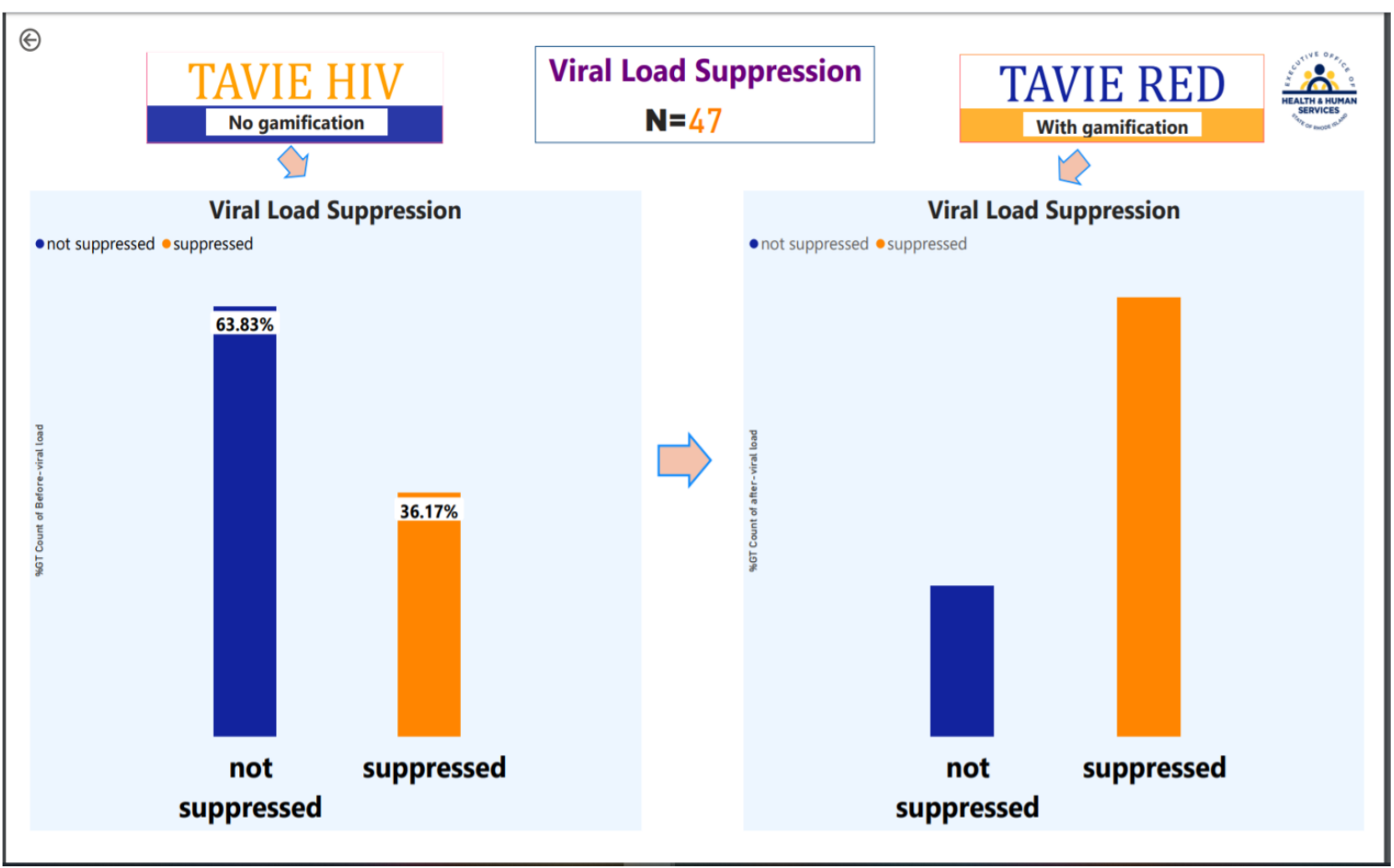

Fiqure 4. Viral load suppression

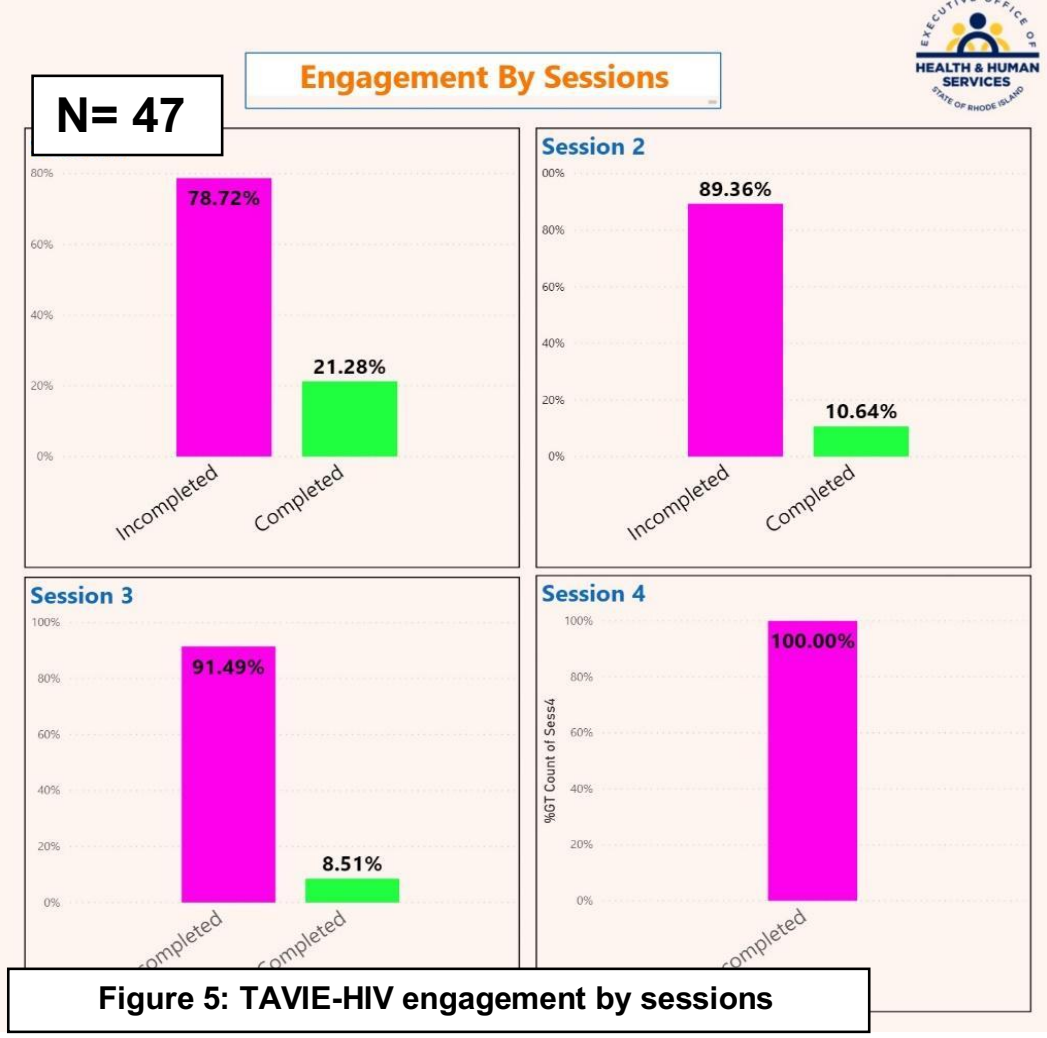




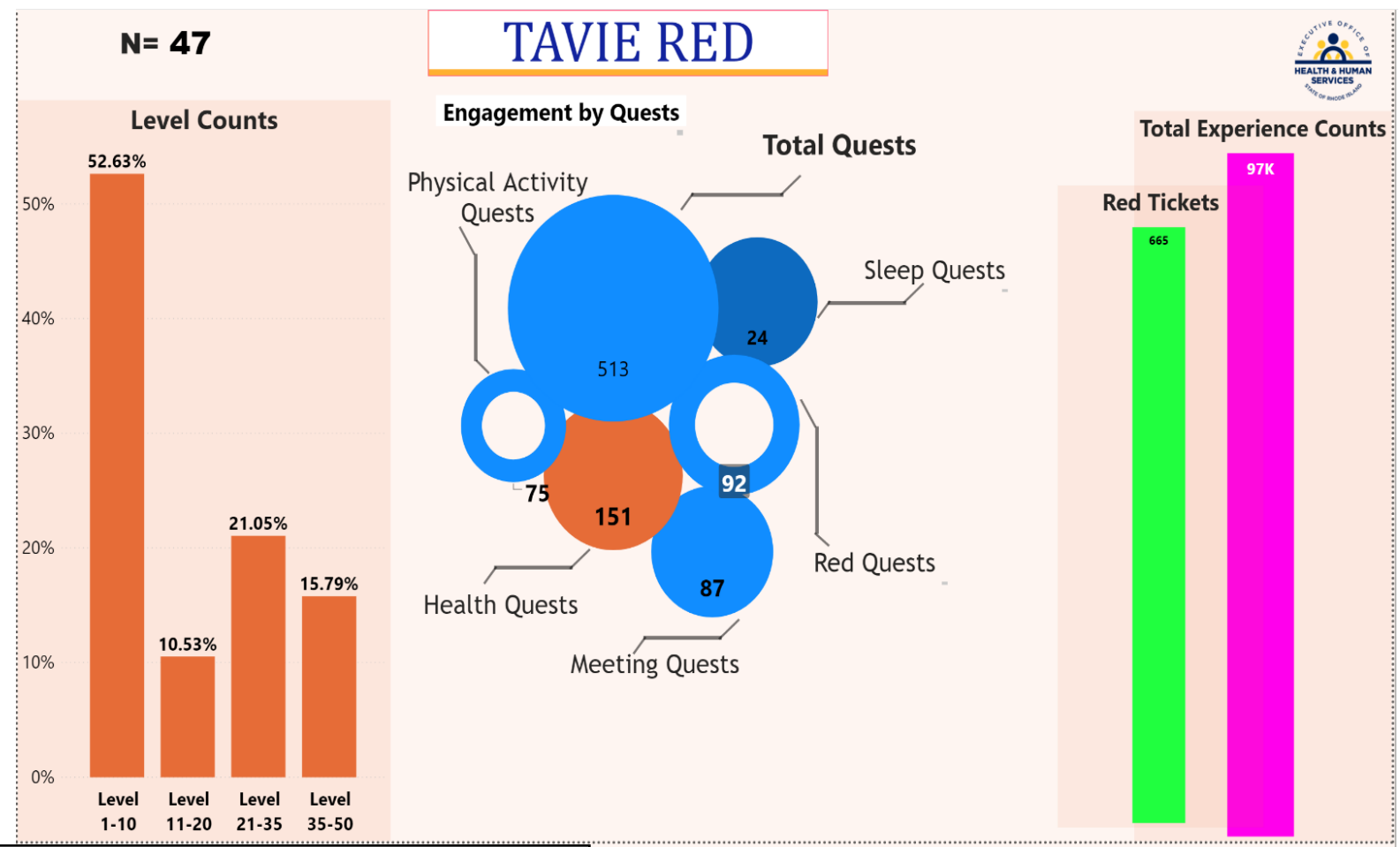

Figure 6. Initial cohort- TAVIE-RED

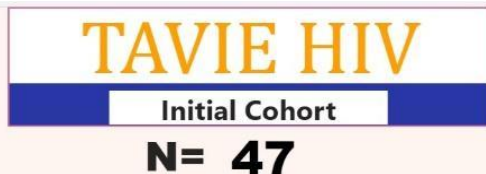

\section{Engagement By Assessments}

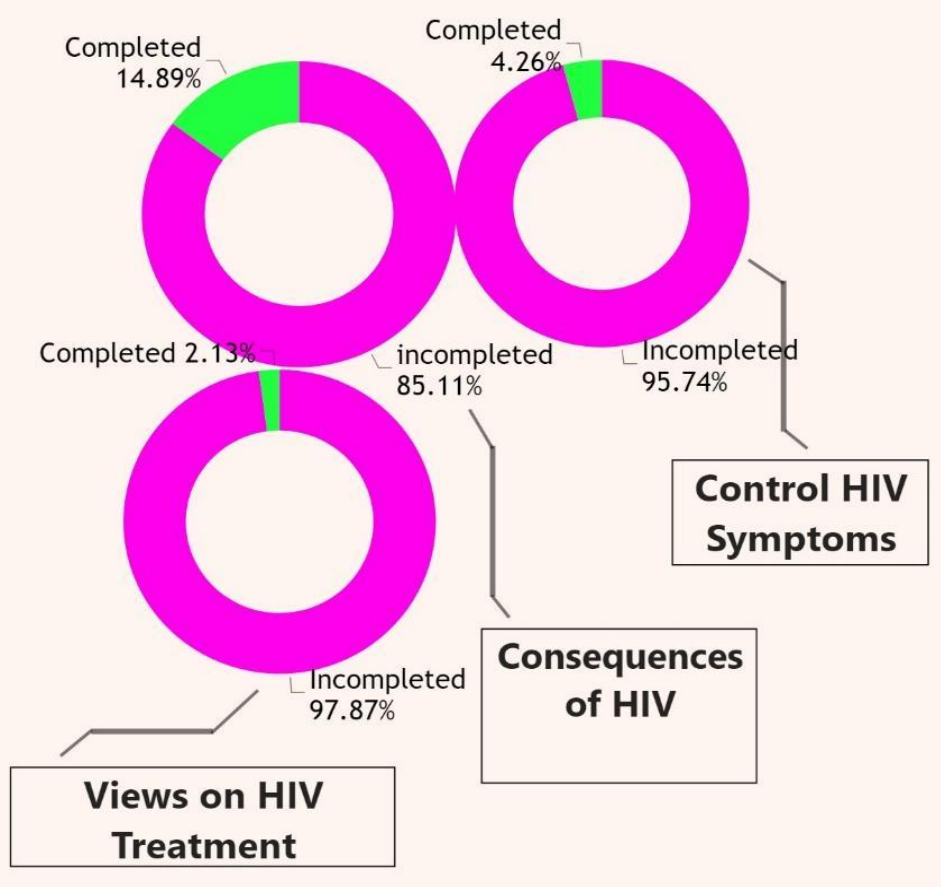

Figure 7: TAVIE-HIV engagement by assessments 


\section{Appendix A. The TAVIE-HIV assessments and descriptions}

\begin{tabular}{|l|l|}
\hline \multicolumn{1}{|c|}{ Assessment/Questionnaire } & \multicolumn{1}{c|}{ Descriptions } \\
\hline $\begin{array}{l}\text { Session 1: Managing } \\
\text { medication }\end{array}$ & HIV-Education, Motivation and side-effect management \\
\hline $\begin{array}{l}\text { Session 2: Emotional } \\
\text { Management }\end{array}$ & $\begin{array}{l}\text { Emotional management and problem-solving skill- } \\
\text { development }\end{array}$ \\
\hline $\begin{array}{l}\text { Session 3: Communication } \\
\text { and Social }\end{array}$ & $\begin{array}{l}\text { Coaching and positive reinforcement to improve } \\
\text { communication within the community, Family and with care- } \\
\text { providers }\end{array}$ \\
\hline $\begin{array}{l}\text { Session 4: Reviews } \\
\text { 4.1. Optimism }\end{array}$ & $\begin{array}{l}\text { 4.1. Life Orientation Test to assess optimism vs pessimism in } \\
\text { our HIV population }\end{array}$ \\
4.2. HIV knowledge & $\begin{array}{l}\text { 4.3. Screening and follow-up of anxiety and stress on regular } \\
\text { basis, with visual representation of results for empowerment } \\
\text { and reinforcement of self-monitoring }\end{array}$ \\
4.4. Anxiety & Alcohol drinking
\end{tabular}

Note. The list of assessments in TAVIE-HIV platform

Appendix B. The TAVIE-RED, well-being quests and their descriptions.

\begin{tabular}{|c|c|}
\hline Quests & Descriptions \\
\hline $\begin{array}{l}\text { Well-Being Quest: } \\
\text { 1. Calm and relax } \\
\text { 2. Walking } \\
\text { meditation } \\
\text { 3. Zen quest } \\
\text { 4. Share with a } \\
\text { close one } \\
\text { 5. Three good } \\
\text { things } \\
\text { 6. Being Positive }\end{array}$ & $\begin{array}{l}\text { 1. To go over some calming and relaxation exercise to manage } \\
\text { anxiety and stressful situations } \\
\text { 2. To take a walk in a different way. This exercise helps people } \\
\text { relax and focus their mind } \\
\text { 3. To manage stress and anxiety in a clean and tidy } \\
\text { environment } \\
\text { 4. To visit someone close to you } \\
\text { 5. To take some time at the end of the day to write down three } \\
\text { good things that happened to you each day } \\
\text { 6. Changing your mindset can change the things you can do }\end{array}$ \\
\hline
\end{tabular}




\begin{tabular}{|l|l|}
\hline 7. $\begin{array}{l}\text { Be good to } \\
\text { yourself }\end{array}$ & 7. Techniques to stay strong in the face of stigma \\
8. $\begin{array}{l}\text { All the good } \\
\text { things }\end{array}$ & \\
\hline
\end{tabular}

Note. Well-being quests guide users on their emotional health journey with different health assessments and activities that would benefit their health.

Appendix C. The TAVIE-RED, your health quests and their descriptions.

\begin{tabular}{|c|c|}
\hline Quests & Descriptions \\
\hline $\begin{array}{l}\text { Your Health: } \\
\text { 1. Your pillbox } \\
\text { 2. Take a walk } \\
\text { 3. Communication } \\
\text { 4. Take a longer walk } \\
\text { 5. Health check up } \\
\text { 6. Chat with your } \\
\text { doctor } \\
\text { 7. Developing good } \\
\text { habits } \\
\text { 8. Decide to make it } \\
\text { work } \\
\text { 9. Meds in Check }\end{array}$ & $\begin{array}{l}\text { 1. To guide user through entering treatments and setting up } \\
\text { treatment reminder } \\
\text { 2. To take a walk around the block } \\
\text { 3. To go over communication skills with friends and close } \\
\text { ones } \\
\text { 4. To encourage client to take a longer walk } \\
\text { 5. To add the symptoms to keep up to date and help prevent } \\
\text { serious issues } \\
\text { 6. To provide communication skills session to make sure } \\
\text { users are comfortable talking to their healthcare providers } \\
\text { 7. How to stay motivated to take the medication regularly } \\
\text { 8. To cope with situations that can make it difficult to take } \\
\text { 9our medication } \\
\text { 9. How to manage medication side effects }\end{array}$ \\
\hline
\end{tabular}

Note. Your Health quests are focused on overall health activities such as physical health quests that have clients take a walk or exercise.

Appendix D. The TAVIE-RED, sleep insomnia quests and their descriptions.

\begin{tabular}{|c|c|}
\hline Quests & Descriptions \\
\hline $\begin{array}{l}\text { Sleep Insomnia: } \\
\text { 1. Introduction to sleep } \\
\text { 2. Sleep and your } \\
\text { medications } \\
\text { 3. Act to sleep } \\
\text { 4. Sleep hygiene and } \\
\text { sleep environment } \\
\text { 5. Re-thinking sleep } \\
\text { 6. Sleep aids } \\
\text { 7. Try to sleep diary } \\
\text { 8. About sleep Apnea } \\
\text { 9. Sleep rituals }\end{array}$ & $\begin{array}{l}\text { 1. Introduction to the sleep quest } \\
\text { 2. To schedule when to sleep and to take medication } \\
\text { because some medications have side effects that impact } \\
\text { sleep } \\
\text { 3. To learn techniques and activities that can be done to } \\
\text { improve sleep } \\
\text { 4. To learn about things can be done to prepare the } \\
\text { sleeping space in a relaxing, and restful } \\
\text { 5. To go through some common wrong beliefs and other } \\
\text { ways to think about sleep } \\
\text { 6. To learn new techniques and things to do before bed } \\
\text { that would help lead to a pleasant sleep }\end{array}$ \\
\hline
\end{tabular}


7. User will keep a sleep diary for a few days to have a better idea of how much sleep they get and how they can improve it

8. To discuss sleep Apnea and do a short questionnaire to assess if one is a risk of having it

9. To practice the sleep rituals for a good night's sleep

Note. The sleep insomnia quests are specifically designed to support sleep with different kinds of meditation styles. Users can practice meditating directly right from the application, as it is provided in the application itself with guidance and meditation music.

Appendix E. The TAVIE-RED, meeting quests and their descriptions.

\begin{tabular}{|l|l|}
\hline \multicolumn{1}{|c|}{ Quests } & \multicolumn{1}{c|}{ Descriptions } \\
\hline Meeting Quest: & $\begin{array}{l}\text { 1. To help scheduling and preparing to see the dentist } \\
\text { 2. To help scheduling and preparing for the therapy } \\
\text { appointment }\end{array}$ \\
$\begin{array}{l}\text { 1. Go to the dentist } \\
\text { 2. Go to a therapist } \\
\text { 3. See your doctor } \\
\begin{array}{l}\text { 4. See your case } \\
\text { manager }\end{array}\end{array} \quad \begin{array}{l}\text { To help scheduling and preparing for the doctor's } \\
\text { To help scheduling and prepare for the case management } \\
\text { appointment } \\
\text { 5. Healthy weight }\end{array}$ & $\begin{array}{l}\text { To provide the steps that can help users manage their } \\
\text { weight }\end{array}$ \\
\hline
\end{tabular}

Note. These quests are designed to encourage clients to attend their medical appointments with their providers such as their medical doctors, nurses, therapists, and case managers. In order to complete this quest, users will have to attend a scheduled medical appointment.

Appendix F. The TAVIE-RED, red quests and their descriptions.

\begin{tabular}{|c|c|}
\hline Quests & Descriptions \\
\hline $\begin{array}{l}\text { Red Quest: } \\
\text { 1. Set up the } \\
\text { application } \\
\text { 2. Run an errand } \\
\text { 3. Women and HIV } \\
\text { 4. Pregnancy and } \\
\text { HIV } \\
\text { 5. Birth control and } \\
\text { HIV } \\
\text { 6. Menopause and } \\
\text { HIV }\end{array}$ & $\begin{array}{l}\text { 1. To provide a quick tour of the TAVIE-RED application and } \\
\text { set it up to fit the user's preferences } \\
\text { 2. Introduce the application and how it can help the user get } \\
\text { errands done with it } \\
\text { 3. To go over women's health and needs } \\
\text { 4. To go over what it means and how to plan a pregnancy for } \\
\text { women living with HIV } \\
\text { 5. To go over the basics of birth control and what to know for } \\
\text { women with HIV } \\
\text { 6. To dive into the different aspects of menopause and how to } \\
\text { manage them }\end{array}$ \\
\hline
\end{tabular}


Note. Red quest contains a variety of information that users will find helpful. It has guidance on how to use the application, how to set appointments on the application, and educational quests on HIV pregnancy and how to take care of oneself while being pregnant.

\section{Appendix G. TAVIE-HIV: Demographics}

\begin{tabular}{|c|c|c|c|}
\hline \multicolumn{2}{|l|}{$\begin{array}{l}\text { Age (years): } 18-65+ \\
\mathrm{N}=131 ; \text { Missing }=0\end{array}$} & \multicolumn{2}{|c|}{$\begin{array}{c}\text { Mean age }=3.21 \\
(\mathrm{SD}=0.942) \\
\text { Range }=5\end{array}$} \\
\hline \multicolumn{2}{|r|}{ Variables } & Number & Percentage \\
\hline \multirow[t]{4}{*}{ Gender } & Female & 52 & 39.69 \\
\hline & Male & 76 & 58.01 \\
\hline & Transgender & $*$ & $*$ \\
\hline & Missing & $*$ & $*$ \\
\hline \multirow[t]{7}{*}{ Race } & American Indian or Alaska Native & $*$ & $*$ \\
\hline & Asian & $*$ & $*$ \\
\hline & Black or African American & 35 & 26.72 \\
\hline & Hispanic or Latino & 35 & 26.72 \\
\hline & White & 41 & $31.29 *$ \\
\hline & Multiracial & 15 & 11.45 \\
\hline & Missing & $*$ & $*$ \\
\hline \multirow[t]{5}{*}{ Age } & 18 to 24 years & $*$ & $*$ \\
\hline & 25 to 44 years & 31 & 23.66 \\
\hline & 45 to 54 years & 42 & $32.06^{*}$ \\
\hline & 55 to 64 years & 49 & $37.40^{*}$ \\
\hline & Age 65 and above & $*$ & $*$ \\
\hline \multirow[t]{4}{*}{ Education } & Less than high school, no diploma & 38 & 29.01 \\
\hline & $\begin{array}{l}\text { High school graduate, diploma or the } \\
\text { equivalent }\end{array}$ & 59 & 45.04 \\
\hline & Bachelor's degree & 32 & 24.43 \\
\hline & Missing & $*$ & $*$ \\
\hline \multirow[t]{3}{*}{ Employment Status } & Employed or self-employed & 16 & 12.40 \\
\hline & Unemployed & 106 & $82.17 * *$ \\
\hline & Missing & $*$ & $*$ \\
\hline \multirow[t]{4}{*}{ Housing Status } & Permanent (rent or own) & 79 & $61.72 * *$ \\
\hline & Temporary & 15 & 11.72 \\
\hline & Homeless & 14 & 10.94 \\
\hline & Missing & 20 & 15.63 \\
\hline \multirow[t]{4}{*}{ Marital Status } & Single/never married & 72 & 56.25 \\
\hline & Married & 16 & 12.21 \\
\hline & Widowed & $*$ & $*$ \\
\hline & Divorced or separated & 14 & 10.94 \\
\hline
\end{tabular}




\begin{tabular}{|c|c|c|c|}
\hline & Domestic partner & $*$ & $*$ \\
\hline & Missing & * & * \\
\hline \multirow[t]{8}{*}{ Health insurance } & Uninsured & $*$ & $*$ \\
\hline & Medicaid only & 48 & 37.50 \\
\hline & Medicare only & 25 & 19.53 \\
\hline & Other Public only & $*$ & * \\
\hline & Private only & $*$ & $*$ \\
\hline & Other only & $*$ & * \\
\hline & Multiple types & 17 & 13.28 \\
\hline & Missing & 24 & 18.75 \\
\hline \multirow[t]{3}{*}{ Medication coverage } & Yes & 97 & 91.51 \\
\hline & No & * & * \\
\hline & Missing & 32 & 24.42 \\
\hline \multirow[t]{7}{*}{ HIV risk factors } & Men who have sex with men & 37 & 28.24 \\
\hline & Intravenous drug use & 11 & 8.40 \\
\hline & Alcohol abuse & $*$ & $*$ \\
\hline & Hemophilia/Coagulation disorders & $*$ & * \\
\hline & Heterosexual & 51 & 38.93 \\
\hline & $\begin{array}{l}\text { Receipt of blood transfusions, } \\
\text { blood components or tissue }\end{array}$ & $*$ & $*$ \\
\hline & Mother with HIV & $*$ & $*$ \\
\hline \multirow{4}{*}{$\begin{array}{l}\text { Victim of domestic } \\
\text { violence }\end{array}$} & Yes & $*$ & * \\
\hline & No & 107 & 81.68 \\
\hline & Not applicable & 11 & 8.40 \\
\hline & Missing & $*$ & $*$ \\
\hline
\end{tabular}

Note. $*=\mathrm{N}<10$. This is used to protect users' confidentiality 


\section{Appendix H. TAVIE-RED Demographics}

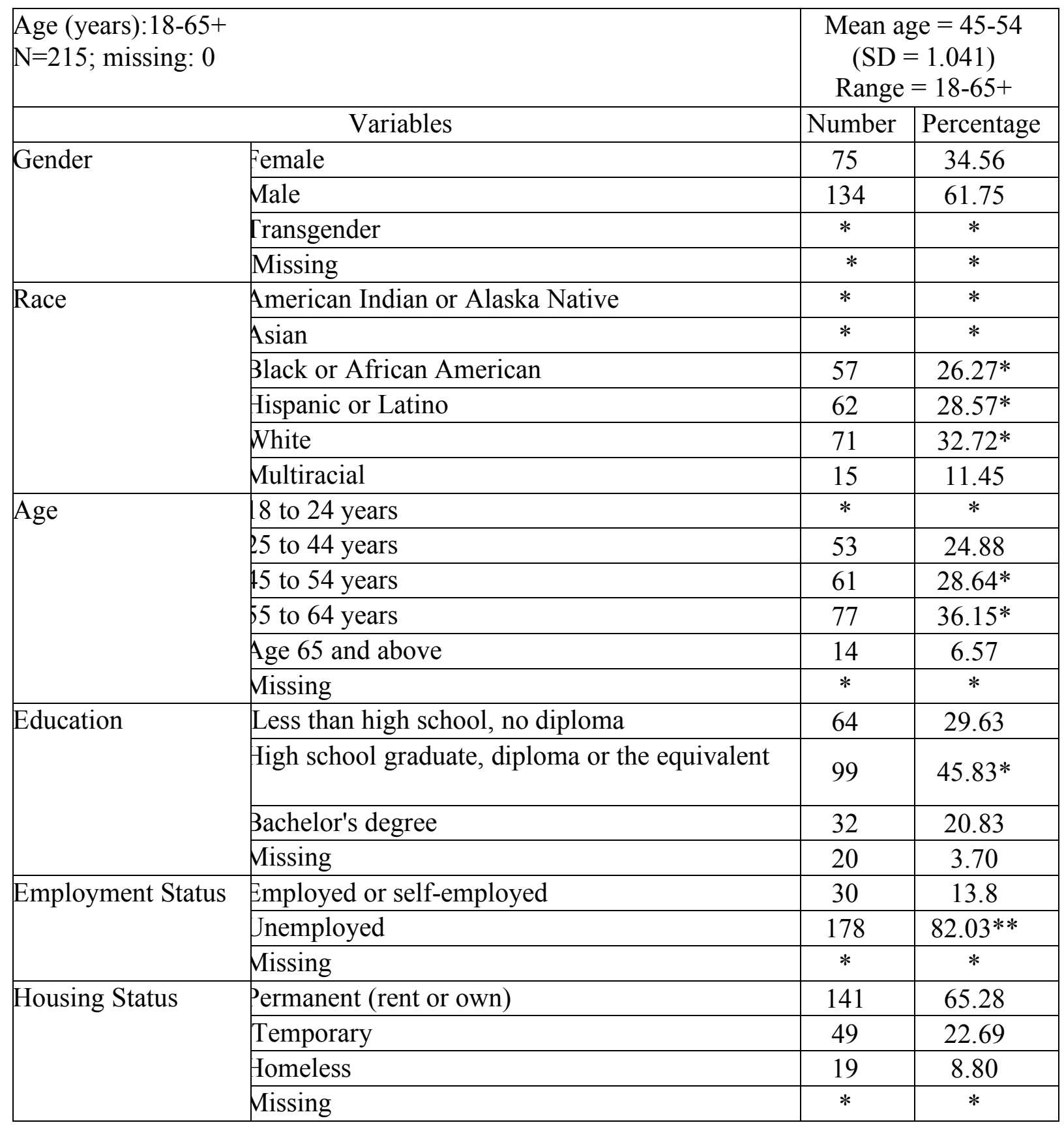

Marital Status 


\begin{tabular}{|c|c|c|c|}
\hline & Married & 18 & 8.29 \\
\hline & Widowed & $*$ & $*$ \\
\hline & Divorced or separated & 38 & 17.51 \\
\hline & Pomestic partner & $*$ & $*$ \\
\hline & Missing & $*$ & * \\
\hline \multirow[t]{4}{*}{ Housing Status } & Permanent (rent or own) & 141 & 64.98 \\
\hline & Temporary (shelter, family/friends, facility) & 49 & 22.58 \\
\hline & Homeless or unstable & 19 & 8.76 \\
\hline & Missing & $*$ & $*$ \\
\hline \multirow[t]{6}{*}{ Health insurance } & Jninsured & $*$ & $*$ \\
\hline & Medicaid & 135 & 62.21 \\
\hline & Medicare & 86 & 39.63 \\
\hline & Pther Public & 19 & 8.76 \\
\hline & Private & 19 & 8.76 \\
\hline & Missing & $*$ & * \\
\hline \multirow[t]{2}{*}{ Medication coverage } & Yes & 199 & $91.71 \%$ \\
\hline & No & 18 & $8.29 \%$ \\
\hline \multirow[t]{7}{*}{ HIV risk factors } & Men who have sex with men & 64 & $29.49 \%$ \\
\hline & Intravenous drug use & 29 & $13.36 \%$ \\
\hline & Alcohol abuse & 15 & $6.91 \%$ \\
\hline & Hemophilia/Coagulation disorders & $*$ & $*$ \\
\hline & Heterosexual & 84 & $38.71 \%$ \\
\hline & $\begin{array}{l}\text { Receipt of blood transfusions, blood components } \\
\text { or tissue }\end{array}$ & $*$ & $*$ \\
\hline & Mother with HIV & 25 & $11.52 \%$ \\
\hline \multirow{4}{*}{$\begin{array}{l}\text { Victim of domestic } \\
\text { violence }\end{array}$} & Yes & 16 & $7.37 \%$ \\
\hline & No & 172 & $79.26 \%$ \\
\hline & Not applicable & 11 & $5.07 \%$ \\
\hline & Missing & 18 & $8.29 \%$ \\
\hline
\end{tabular}

Note. $*=\mathrm{N}<10$. This is used to protect users' confidentiality

\section{Appendix I. TAVIE-HIV: Depression Severity Level}




\begin{tabular}{|l|l|l|}
\hline Depression Severity Level & Number & Percent \\
\hline None & $*$ & 3.8 \\
\hline Mild & 11 & 8.4 \\
\hline Moderate & 37 & 28.2 \\
\hline Moderately Severe & 39 & 29.8 \\
\hline Severe & 39 & 29.8 \\
\hline Total & 131 & 100 \\
\hline
\end{tabular}

Note. $*=\mathrm{N}<10$

Appendix J. TAVIE-RED: Depression Severity Levels

\begin{tabular}{|l|l|l|}
\hline Depression Severity Level & Number & Percent \\
\hline None & $*$ & $*$ \\
\hline Moderate & 63 & 29.3 \\
\hline Moderately Severe & 47 & 21.9 \\
\hline Severe & 99 & 46.0 \\
\hline Total & 215 & 100 \\
\hline
\end{tabular}

Note. $*=\mathrm{N}<10$ 
Appendix K. TAVIE-HIV: Depression Severity (PHQ9)

$(\mathrm{N}=131)$

\begin{tabular}{|c|c|c|c|c|c|c|c|}
\hline \multicolumn{2}{|c|}{ Variables } & \multicolumn{6}{|c|}{ Depression Severity } \\
\hline \multicolumn{2}{|c|}{ No of participants } & None & Mild & Moderate & Moderately & Severe & Total \\
\hline \multirow{5}{*}{ Gender } & Female & $*$ & $*$ & 14 & 13 & 17 & 50 \\
\hline & Male & $*$ & $*$ & 21 & 24 & 21 & 76 \\
\hline & Transgender & $*$ & $*$ & $*$ & $*$ & $*$ & $*$ \\
\hline & Missing & $*$ & * & $*$ & * & $*$ & $*$ \\
\hline & Total: & $*$ & 11 & 37 & 39 & 39 & 131 \\
\hline \multirow[t]{7}{*}{ Race } & $\begin{array}{l}\text { American Indian or } \\
\text { Alaska Native }\end{array}$ & $*$ & $*$ & $*$ & $*$ & * & $*$ \\
\hline & Asian & $*$ & $*$ & $*$ & $*$ & $*$ & $*$ \\
\hline & $\begin{array}{l}\text { Black or African } \\
\text { American }\end{array}$ & $*$ & $*$ & 12 & $*$ & $*$ & 35 \\
\hline & Hispanic or Latino & $*$ & $*$ & 10 & 10 & 10 & 35 \\
\hline & White & $*$ & $*$ & $*$ & 14 & 10 & 33 \\
\hline & Multiracial & $*$ & $*$ & $*$ & $*$ & $*$ & $*$ \\
\hline & Missing & $*$ & $*$ & $*$ & $*$ & $*$ & 18 \\
\hline
\end{tabular}




\begin{tabular}{|c|c|c|c|c|c|c|c|}
\hline & Total: & * & $*$ & 63 & 47 & 99 & 131 \\
\hline \multirow{7}{*}{ Age } & 18 to 24 years & * & * & * & * & * & * \\
\hline & 25 to 44 years & * & $*$ & * & 12 & * & 31 \\
\hline & 45 to 54 years & * & * & $*$ & * & 16 & 42 \\
\hline & 55 to 64 years & * & $*$ & 20 & 13 & 10 & 49 \\
\hline & Age 65 and above & * & * & * & $*$ & * & * \\
\hline & Missing & * & * & * & * & * & * \\
\hline & Total: & $*$ & 11 & 37 & 39 & 39 & 131 \\
\hline \multirow[t]{4}{*}{ Education } & $\begin{array}{l}\text { Less than high } \\
\text { school, no diploma }\end{array}$ & $*$ & $*$ & 10 & 11 & 13 & 38 \\
\hline & $\begin{array}{l}\text { High school } \\
\text { graduate, diploma } \\
\text { or the equivalent }\end{array}$ & $*$ & $*$ & 18 & 16 & 17 & 59 \\
\hline & Bachelor's degree & $*$ & $*$ & $*$ & 11 & $*$ & 32 \\
\hline & Total: & * & 11 & 37 & 39 & 39 & 131 \\
\hline \multirow{2}{*}{$\begin{array}{l}\text { Employment } \\
\text { Status }\end{array}$} & $\begin{array}{l}\text { Employed or self- } \\
\text { employed }\end{array}$ & $*$ & * & * & * & * & 16 \\
\hline & Unemployed & $*$ & $*$ & 31 & 28 & 36 & 106 \\
\hline
\end{tabular}




\begin{tabular}{|c|c|c|c|c|c|c|c|}
\hline & Missing & $*$ & * & $*$ & $*$ & $*$ & $*$ \\
\hline & Total: & $*$ & 11 & 37 & 38 & 39 & 131 \\
\hline Housing & $\begin{array}{l}\text { Permanent (rent or } \\
\text { own) }\end{array}$ & $*$ & $*$ & 22 & 23 & 26 & 79 \\
\hline & $\begin{array}{l}\text { Temporary (shelter, } \\
\text { family/friends, } \\
\text { facility) }\end{array}$ & $*$ & * & $*$ & $*$ & $*$ & 15 \\
\hline & $\begin{array}{l}\text { Homeless or } \\
\text { Unstable housing }\end{array}$ & $*$ & $*$ & $*$ & $*$ & * & 14 \\
\hline & Missing & $*$ & * & $*$ & $*$ & $*$ & 20 \\
\hline & Total: & $*$ & 11 & 37 & 38 & 38 & 131 \\
\hline
\end{tabular}

Note. $*=\mathrm{N}<10$. This is used to protect users' confidentiality 
Appendix L. TAVIE-RED: Depression Severity (PHQ-9)

$(\mathrm{N}=215)$

\begin{tabular}{|c|c|c|c|c|c|c|}
\hline \multicolumn{2}{|c|}{ Variables } & \multicolumn{5}{|c|}{ Depression Severity } \\
\hline \multicolumn{2}{|c|}{ No of participants } & None & Moderate & Moderately & Severe & Total \\
\hline \multirow{4}{*}{ Gender } & Female & $*$ & 13 & 21 & 38 & 75 \\
\hline & Male & $*$ & 48 & 25 & 58 & 134 \\
\hline & Transgender & $*$ & * & $*$ & $*$ & $*$ \\
\hline & Missing & $*$ & $*$ & $*$ & $*$ & $*$ \\
\hline \multirow[t]{6}{*}{ Race } & $\begin{array}{l}\text { American Indian } \\
\text { or Alaska Native }\end{array}$ & $*$ & $*$ & $*$ & $*$ & $*$ \\
\hline & Asian & $*$ & $*$ & $*$ & $*$ & $*$ \\
\hline & $\begin{array}{l}\text { Black or African } \\
\text { American }\end{array}$ & $*$ & 22 & 15 & 19 & 57 \\
\hline & $\begin{array}{l}\text { Hispanic or } \\
\text { Latino }\end{array}$ & $*$ & 23 & 10 & 26 & 62 \\
\hline & White & $*$ & 12 & 17 & 42 & 71 \\
\hline & Multiracial & $*$ & $*$ & $*$ & $*$ & 15 \\
\hline \multirow{3}{*}{ Age } & 18 to 24 years & $*$ & $*$ & $*$ & $*$ & $*$ \\
\hline & 25 to 44 years & $*$ & 13 & 16 & 24 & 53 \\
\hline & 45 to 54 years & $*$ & 16 & 14 & 28 & 61 \\
\hline
\end{tabular}




\begin{tabular}{|c|c|c|c|c|c|c|}
\hline & 55 to 64 years & * & 24 & 11 & 40 & 77 \\
\hline & $\begin{array}{l}\text { Age } 65 \text { and } \\
\text { above }\end{array}$ & $*$ & $*$ & $*$ & $*$ & 14 \\
\hline \multirow[t]{4}{*}{ Education } & $\begin{array}{l}\text { Less than high } \\
\text { school, no } \\
\text { diploma }\end{array}$ & $*$ & 19 & * & 31 & 64 \\
\hline & $\begin{array}{l}\text { High school } \\
\text { graduate, } \\
\text { diploma or the } \\
\text { equivalent }\end{array}$ & $*$ & 24 & 24 & 48 & 99 \\
\hline & $\begin{array}{l}\text { Bachelor's } \\
\text { degree }\end{array}$ & $*$ & 17 & $*$ & 19 & 45 \\
\hline & Missing & * & * & * & * & * \\
\hline \multirow[t]{3}{*}{ Employment Status } & $\begin{array}{l}\text { Employed or } \\
\text { self-employed }\end{array}$ & $*$ & 10 & * & 13 & * \\
\hline & Unemployed & * & 51 & $*$ & 84 & 30 \\
\hline & Missing & $*$ & $*$ & 38 & $*$ & 178 \\
\hline \multirow[t]{3}{*}{ Housing Status } & $\begin{array}{l}\text { Permanent (rent } \\
\text { or own) }\end{array}$ & $*$ & 48 & 31 & 58 & 141 \\
\hline & $\begin{array}{l}\text { Temporary } \\
\text { (shelter, } \\
\text { family/friends, } \\
\text { facility) }\end{array}$ & $*$ & * & 13 & 25 & 49 \\
\hline & $\begin{array}{l}\text { Homeless or } \\
\text { Unstable } \\
\text { housing }\end{array}$ & $*$ & $*$ & $*$ & 14 & 19 \\
\hline
\end{tabular}

Note. $*=\mathrm{N}<10$. This is used to protect users' confidentiality 
Appendix M. TAVIE-HIV and TAVIE-RED- Viral Load Suppression

\begin{tabular}{|c|c|c|c|c|c|c|}
\hline \multicolumn{7}{|c|}{$\begin{array}{l}\text { Age (years): } 18-65+ \\
\mathrm{N}=47 ; \text { Missing }=0\end{array}$} \\
\hline \multirow{2}{*}{\multicolumn{2}{|c|}{ Variables }} & \multirow{3}{*}{$\begin{array}{c}\text { Number } \\
\text { (Percentage) } \\
\\
21 \\
(44.68 \%)\end{array}$} & \multicolumn{2}{|c|}{$\begin{array}{l}\text { Viral Load Suppression } \\
\text { (Before) }\end{array}$} & \multicolumn{2}{|c|}{$\begin{array}{l}\text { Viral Load Suppression } \\
\text { (After) }\end{array}$} \\
\hline & & & Suppressed & $\begin{array}{c}\text { Not } \\
\text { Suppressed }\end{array}$ & Suppressed & $\begin{array}{c}\text { Not } \\
\text { Suppressed }\end{array}$ \\
\hline \multirow[t]{2}{*}{ Gender } & Female & & $*$ & 13 & 15 & $*$ \\
\hline & Male & $\begin{array}{c}25 \\
(53.19 \%)\end{array}$ & $*$ & 16 & 19 & $*$ \\
\hline \multirow[t]{8}{*}{ Race } & $\begin{array}{l}\text { Black or African } \\
\text { American }\end{array}$ & $\begin{array}{c}12 \\
(25.53 \%)\end{array}$ & $*$ & $*$ & 10 & $*$ \\
\hline & $\begin{array}{l}\text { Hispanic or } \\
\text { Latino }\end{array}$ & $\begin{array}{c}13 \\
(27.65 \%)\end{array}$ & $*$ & 10 & $*$ & $*$ \\
\hline & White & $\begin{array}{c}17 \\
(38.29 \%)\end{array}$ & $*$ & 11 & 13 & $*$ \\
\hline & Multiracial & $*$ & $*$ & $*$ & $*$ & $*$ \\
\hline & 25 to 44 years & $\begin{array}{c}11 \\
(23.40 \%)\end{array}$ & $*$ & 10 & $*$ & $*$ \\
\hline & 45 to 54 years & $\begin{array}{c}14 \\
(29.78 \%)\end{array}$ & $*$ & $*$ & 11 & $*$ \\
\hline & 55 to 64 years & $\begin{array}{c}17 \\
(36.17 \%)\end{array}$ & $*$ & 12 & 15 & $*$ \\
\hline & $\begin{array}{l}\text { Age } 65 \text { and } \\
\text { above }\end{array}$ & $*$ & $*$ & $*$ & $*$ & $*$ \\
\hline \multirow[t]{2}{*}{ Education } & $\begin{array}{l}\text { Less than high } \\
\text { school, no } \\
\text { diploma }\end{array}$ & $\begin{array}{c}11 \\
(23.40 \%)\end{array}$ & $*$ & $*$ & $*$ & $*$ \\
\hline & $\begin{array}{l}\text { High school } \\
\text { graduate, } \\
\text { diploma or the } \\
\text { equivalent }\end{array}$ & $\begin{array}{c}26 \\
(55.31 \%)\end{array}$ & $*$ & 18 & 18 & $*$ \\
\hline
\end{tabular}




\begin{tabular}{|c|l|c|c|c|c|c|}
\hline & $\begin{array}{l}\text { Bachelor's } \\
\text { degree }\end{array}$ & $*$ & $*$ & $*$ & $*$ & $*$ \\
\hline \multirow{2}{*}{$\begin{array}{c}\text { Employment } \\
\text { Status }\end{array}$} & $\begin{array}{l}\text { Employed or } \\
\text { self-employed }\end{array}$ & $*$ & $*$ & $*$ & $*$ & $*$ \\
\cline { 2 - 6 } & Unemployed & $\begin{array}{c}38 \\
(80.85 \%)\end{array}$ & 14 & 24 & 28 & 10 \\
\hline \multirow{2}{*}{$\begin{array}{c}\text { Housing } \\
\text { Status }\end{array}$} & $\begin{array}{l}\text { Permanent (rent } \\
\text { or own) }\end{array}$ & $\begin{array}{c}36 \\
(76.59 \%)\end{array}$ & 14 & 22 & 25 & 11 \\
\cline { 2 - 7 } & Temporary & $*$ & $*$ & $*$ & $*$ & $*$ \\
\cline { 2 - 7 } & Homeless & $*$ & $\begin{array}{c}17 \\
(36.17 \%)\end{array}$ & $\begin{array}{c}30 \\
(63.82 \%)\end{array}$ & $\begin{array}{c}35 \\
(74.46 \%)\end{array}$ & $\begin{array}{c}12 \\
(25.53 \%)\end{array}$ \\
\hline \multicolumn{2}{|c|}{ Total Unduplicated Clients: } & & & $*$ & $*$ \\
\hline
\end{tabular}

Note. ${ }^{*}=\mathrm{N}<10$. This is used to protect users' confidentiality 
Appendix N. Tavie Red Engagement by Quests Completion

\begin{tabular}{|c|c|c|c|c|c|c|c|c|c|c|c|}
\hline \multirow{2}{*}{\multicolumn{2}{|c|}{$\begin{array}{r}\text { Age (years): } 18-65+ \\
\mathrm{N}=47 \text {; Missing }=0 \\
\text { Variables }\end{array}$}} & \multicolumn{10}{|c|}{ TAVIE-RED Engagement by Quests Completion } \\
\hline & & \multirow{2}{*}{$\begin{array}{c}\text { Number } \\
\text { (Percent) } \\
\\
21 \\
(44.68 \%)\end{array}$} & \multirow{2}{*}{$\begin{array}{c}\text { Meeting } \\
\text { Quests } \\
\\
\\
38\end{array}$} & \multirow{2}{*}{$\begin{array}{c}\text { Physical } \\
\text { Activity } \\
40\end{array}$} & \multirow{2}{*}{$\begin{array}{c}\text { Red } \\
\text { Quests } \\
48\end{array}$} & \multirow{2}{*}{$\begin{array}{c}\text { Health } \\
\text { Quests } \\
\\
80\end{array}$} & \multirow{2}{*}{$\begin{array}{c}\text { Well } \\
\text { Being } \\
\text { Quests } \\
64\end{array}$} & \multirow{2}{*}{$\begin{array}{c}\text { Sleep } \\
\text { Quests } \\
\\
\\
*\end{array}$} & \multirow{2}{*}{$\begin{array}{c}\text { Total } \\
\text { Quests } \\
\mathbf{2 5 1}\end{array}$} & \multirow{2}{*}{$\begin{array}{c}\text { Total } \\
\text { Red } \\
\text { Tickets }\end{array}$} & \multirow{2}{*}{$\begin{array}{c}\text { Total } \\
\text { Experiences } \\
\\
\mathbf{5 9 6 8 3}^{*}\end{array}$} \\
\hline Gender & Female & & & & & & & & & & \\
\hline & Male & $\begin{array}{c}25 \\
(53.19 \%)\end{array}$ & 49 & 34 & 44 & 70 & 63 & 19 & 260 & 280 & 29193 \\
\hline & Missing & $*$ & * & $*$ & * & * & 12 & * & 31 & 125 & 8552 \\
\hline \multirow[t]{7}{*}{ Race } & $\begin{array}{l}\text { Black or } \\
\text { African } \\
\text { American }\end{array}$ & $\begin{array}{c}12 \\
(25.53 \%)\end{array}$ & 14 & * & 19 & 21 & 15 & * & 72 & 107 & 6936 \\
\hline & $\begin{array}{l}\text { Hispanic or } \\
\text { Latino }\end{array}$ & $\begin{array}{c}13 \\
(27.65 \%)\end{array}$ & 32 & 26 & 37 & 52 & 43 & $*$ & 175 & 281 & 31650 \\
\hline & White & $\begin{array}{c}17 \\
(38.29 \%)\end{array}$ & 45 & 42 & 37 & 74 & 83 & 25 & 286 & 377 & $58700^{*}$ \\
\hline & Multiracial & * & * & $*$ & $*$ & $*$ & $*$ & $*$ & 12 & 21 & 592 \\
\hline & $\begin{array}{l}25 \text { to } 44 \\
\text { years }\end{array}$ & $\begin{array}{c}11 \\
(23.40 \%)\end{array}$ & 19 & 12 & 18 & 28 & 30 & - & 96 & 174 & 23731 \\
\hline & $\begin{array}{l}45 \text { to } 54 \\
\text { years }\end{array}$ & $\begin{array}{c}14 \\
(29.78 \%)\end{array}$ & 25 & 20 & 27 & 45 & 32 & 10 & 150 & 244 & 8670 \\
\hline & $\begin{array}{l}55 \text { to } 64 \\
\text { years }\end{array}$ & 17 & 38 & 43 & 42 & 71 & 64 & 14 & 248 & 225 & $63683^{*}$ \\
\hline
\end{tabular}




\begin{tabular}{|c|c|c|c|c|c|c|c|c|c|c|c|}
\hline & & $(36.17 \%)$ & & & & & & & & & \\
\hline \multirow[t]{4}{*}{ Education } & $\begin{array}{l}\text { Less than } \\
\text { high school, } \\
\text { no diploma }\end{array}$ & $\begin{array}{c}11 \\
(23.40 \%)\end{array}$ & 12 & 13 & 20 & 30 & 21 & $*$ & 91 & 144 & 6642 \\
\hline & $\begin{array}{l}\text { High school } \\
\text { graduate, } \\
\text { diploma or } \\
\text { the } \\
\text { equivalent }\end{array}$ & $\begin{array}{c}26 \\
(55.31 \%)\end{array}$ & 35 & 26 & 42 & 68 & 53 & $*$ & 207 & 327 & $56267 *$ \\
\hline & $\begin{array}{l}\text { Bachelor's } \\
\text { degree }\end{array}$ & * & 30 & 20 & 17 & 30 & 32 & 18 & 137 & 151 & 17596 \\
\hline & Missing & * & 10 & 16 & 13 & 23 & 22 & $*$ & 78 & 43 & 16923 \\
\hline \multirow[t]{3}{*}{$\begin{array}{l}\text { Employment } \\
\text { Status }\end{array}$} & $\begin{array}{l}\text { Employed } \\
\text { or self- } \\
\text { employed }\end{array}$ & $*$ & 23 & 28 & 24 & 41 & 42 & 14 & 156 & 180 & 33254 \\
\hline & Unemployed & $\begin{array}{c}38 \\
(80.85 \%)\end{array}$ & 63 & 48 & 67 & 109 & 86 & 10 & 354 & 491 & $64168 *$ \\
\hline & Missing & * & $*$ & * & $*$ & * & $*$ & $*$ & * & * & 18 \\
\hline $\begin{array}{l}\text { Housing } \\
\text { Status }\end{array}$ & $\begin{array}{l}\text { Permanent } \\
\text { (rent or } \\
\text { own) }\end{array}$ & $\begin{array}{c}36 \\
(76.59 \%)\end{array}$ & 67 & 53 & 77 & 116 & 97 & 15 & 392 & 559 & $78701 *$ \\
\hline
\end{tabular}




\begin{tabular}{|l|l|l|l|l|l|l|l|l|l|l|l|}
\hline & Temporary & $*$ & 18 & 22 & 15 & 34 & 31 & $*$ & 118 & 97 & 18493 \\
\hline
\end{tabular}

Note. $*=\mathrm{N}<10$. This is used to protect users' confidentialit 
